VIGANÒ, Francesco. "La arbitrariedad del no punir. Sobre las obligaciones de tutela penal de los derechos fundamentales".

Polít. crim. Vol. 9, No 18 (Diciembre 2014), Art. 5, pp. 428-476.

[http://www.politicacriminal.cl/Vol_09/n_18/Vol9N18A5.pdf]

\title{
La arbitrariedad del no punir Sobre las obligaciones de tutela penal de los derechos fundamentales ${ }^{\bullet}$
}

Francesco Viganò

Catedrático de derecho penal en la Università degli Studi di Milano, Italia. francesco.vigano@unimi.it

\section{Resumen}

Tanto la Corte interamericana de San José cuanto el Tribunal europeo de derechos humanos de Estrasburgo han desarrollado la idea según la cual del deber estatal de "respetar" los derechos reconocidos en las respectivas convenciones institutivas derivaría una obligación de tutelar penalmente, cuanto menos los más fundamentales de tales derechos. Más en particular, los Estados tendrían no solo el deber convencional de incriminar las conductas lesivas de los derechos a la vida, a no ser sometido a tortura, a la libertad personal y sexual, etc., sino también el deber de investigar las conductas agresivas de tales derechos ejecutadas por funcionarios públicos o por particulares-, de perseguir penalmente a los sujetos individualizados como responsables y de sancionarlos con penas proporcionales a la gravedad de los hechos cometidos. La presente contribución analiza la jurisprudencia paralela de las dos Cortes en la materia y los argumentos más recurrentes utilizados en sus respectivas sentencias, y luego se cuestiona sobre la problemática justificación de tal cambio de paradigma en la función tradicionalmente atribuida a los derechos humanos en el discurso penal, que de instrumento de defensa del individuo contra la potestad punitiva estatal se convierten acá en un factor que reclama la intervención del derecho penal frente a la elección estatal de no punir.

Palabras clave: Derechos humanos, obligaciones de tutela penal, principio de legalidad, función de la pena.

\begin{abstract}
Tanto la Corte interamericana di San José quanto la Corte europea dei diritti dell'uomo di Strasburgo hanno sviluppato l'idea secondo cui dal dovere statale di "rispettare" i diritti riconosciuti dalle rispettive convenzioni istitutive deriverebbe un obbligo di tutelare

\footnotetext{
- El presente trabajo corresponde a una versión ligeramente modificada del artículo publicado con el título L'arbitrio del non punire. Sugli obblighi di tutela penale dei diritti fondamentali en el libro homenaje al profesor Mario Romano, Studi in Onore di Mario Romano, Napoli: Jovene, 2011, vol. IV, pp. 2645 y ss. Traducción a cargo de Ignacio Castillo V. doctorando de la Università degli Studi di Milano. Colaboró en la traducción Carlos Cabezas C., doctorando de la Università degli Studi di Trento. La revisión final estuvo a cargo del propio autor. Las referencias bibliográficas y jurisprudenciales fueron actualizadas hasta finales de 2010, año de redacción del trabajo.
} 
VIGANÒ, Francesco. "La arbitrariedad del no punir. Sobre las obligaciones de tutela penal de los derechos fundamentales".

penalmente quanto meno i più fondamentali di tali diritti. Più in particolare, gli Stati avrebbero non solo il dovere convenzionale di incriminare le condotte lesive dei diritti alla vita, a non essere sottoposti a tortura, alla libertà personale e sessuale, etc., ma anche il dovere di investigare sulle condotte aggressive di tali diritti - non importa se compiute da agenti pubblici o da privati cittadini -, di perseguire penalmente i soggetti individuati come responsabili e di punirli con pene proporzionate alla gravità del fatto commesso. Il presente contributo analizza la giurisprudenza parallela delle due Corti in materia e gli argomenti più ricorrenti utilizzati nelle rispettive sentenze, e si interroga quindi sulla problematica legittimazione di un simile rovesciamento di paradigma nella funzione tradizionalmente attribuita ai diritti umani nel discorso penalistico, che da strumento di difesa dell'individuo contro la potestà punitiva statale si convertono qui in fattore che reclama l'intervento del diritto penale di fronte alla scelta statale di non punire.

Key words: Diritti umani, obblighi di tutela penale, principio di legalità, funzione della pena.

SUMARIO: 1. ¿Obligaciones de tutela penal? Algunas premisas. - 1.1. Dum Romae consulitur, Saguntum expugnatur. - 1.2. El debate sobre las obligaciones constitucionales de tutela penal y el modelo alemán. - 1.3. Las obligaciones supranacionales de tutela penal como obligaciones constitucionales de tutela penal en virtud del artículo 117 inc. 1 de la Constitución italiana. - 1.4. En particular, las obligaciones supranacionales de tutela de los derechos fundamentales. - 1.5. La relevancia práctica de la cuestión. - 2. La "lucha contra la impunidad" en la jurisprudencia interamericana. - 2.1. La fundamentación teórica de las obligaciones de ciertos derechos fundamentales según la Corte de San José de Costa Rica. - 2.2. Las implicaciones prácticas de esta jurisprudencia. - 2.3. Los (explosivos) efectos sobre los ordenamientos internos. - 3. La paralela jurisprudencia del Tribunal europeo. - 3.1. La progresiva determinación de las obligaciones de tutela penal en la jurisprudencia de Estrasburgo. - 3.2. Las implicaciones prácticas. - 3.3. La proporción de la pena concretamente impuesta respecto a la gravedad de la violación. - 3.4. Efectos internos. - 4. Algunas reflexiones críticas. - 4.1. La problemática legitimación de las obligaciones "positivas" de tutela de los derechos fundamentales mediante el derecho penal. - 4.2. Los argumentos utilizados por las Cortes: la efectividad de la tutela de los derechos y la capacidad disuasiva de la sanción penal. - 4.3. La búsqueda de las razones reales que inspiran la jurisprudencia: a) el nexo entre la tutela jurisdiccional efectiva de la víctima y la punibilidad de la conducta lesiva. - 4.4. (Continuación) La función reparadora, en relación a la víctima, de la pena concretamente impuesta al autor. - 4.5. Sobre la compatibilidad de las obligaciones de tutela penal de los derechos fundamentales con la reserva de ley prevista en el art. 25 inc. 2 de la Constitución italiana. - 5. Conclusiones.

\section{1. ¿Obligaciones de tutela penal? Algunas premisas}

\subsection{Dum Romae consulitur, Saguntum expugnatur}




\section{Polít. crim. Vol. 9, № 18 (Diciembre 2014), Art. 5, pp. 428-476. [http://www.politicacriminal.cl/Vol_09/n_18/Vol9N18A5.pdf]}

Con el desinterés de buena parte de la doctrina penal italiana, uno de los pilares del derecho penal moderno -el principio de la reserva de ley, al cual el Maestro que aquí homenajeamos le ha dedicado estudios memorables, ${ }^{1}$ y que reenvía a la idea del monopolio del legislador en la determinación de los hechos punibles y de las penas correspondientes- está ahora por capitular: o, cuanto menos, está siendo modificado profundamente en su propia fisonomía por, entre otros factores, ${ }^{2}$ las fuentes e instituciones supranacionales que pretenden atar las manos a los legisladores internos, incluso en materia de derecho penal.

La existencia de límites a la discrecionalidad del legislador penal no es, naturalmente, una novedad. Buena parte de las reflexiones penalísticas posteriores a la segunda guerra mundial -en Italia y en otros países- ha estado, por supuesto, dominada por la preocupación de limitar el arbitrio del legislador en materia criminal. Basta pensar en la teoría del bien jurídico como instrumento crítico hacia la legislación vigente, o también en la progresiva elaboración -que constituye quizás el elemento más característico del estilo italiano de "hacer dogmática" penal- de un modelo de derecho penal constitucionalmente orientado: un modelo en el cual principios como culpabilidad, ofensividad, última ratio, han dejado de ser considerados solamente como criterios orientadores de la política criminal, para convertirse en verdaderos y propios cánones de legitimidad constitucional de las leyes penales, capaces por tanto -al menos en las aspiraciones de la doctrina- de invalidar las decisiones normativas que se alejan de tales principios. ${ }^{3}$

Sin embargo, el intento fundamental de estas teorías era aquello de reducir el área de lo penalmente relevante respecto a la voluntad del legislador, ${ }^{4}$ de frente a un dato normativo representado, en Italia, por un código pre-constitucional y de una legislación densamente dominada por preocupaciones de emergencias, incluso después de la segunda guerra mundial. El problema, generalmente advertido por la doctrina penal era, por lo tanto, el exceso de criminalización y/o de respuestas sancionatorias, que se invocaban para contrastar a los principios de rango superior respecto a la normativa ordinaria, de los cuales se esperaba que la Corte constitucional pudiese convertirse en garante.

\footnotetext{
${ }^{1}$ ROMANO, Mario, Repressione della condotta antisindacale. Profili penali, Milano: Giuffrè, 1974; EL MISMO, "Corte costituzionale e riserva di legge", en: VASSALLI, Giuliano (Ed.), Diritto penale e giurisprudenza costituzionale, Napoli: ESI, 2006, pp. 29 y ss.; EL MISMO, "Complessità delle fonti e sistema penale. Leggi regionali, ordinamento comunitario, Corte costituzionale", Rivista italiana di diritto e procedura penale (2008), pp. 538-558, pp. 538 y ss.

${ }^{2}$ Sobre los múltiples ámbitos de la actual crisis de la reserva de ley, en particular sobre la vertiente de su actual incapacidad de mantener la "promesa de garantizar una autentica legitimación democrática de las decisiones de política penal” (p. 1275), cfr. el agudo ensayo de FIANDACA, Giovanni, "Legalità penale e democrazia", en: Quaderni fiorentini per la storia del pensiero giuridico moderno, 2007, pp. 1247 y ss.

${ }^{3}$ DONINI, Massimo, Il volto attuale dell'illecito penale, Milano: Giuffrè, 2004, pp. 66 y ss. En el sentido, por otra parte, de la inidoneidad de los principios de fragmentariedad, subsidiariedad y proporcionalidad para operar como parámetros formales de comparación para la declaración de ilegitimidad constitucional de las normas penales, ya que el contenido concreto de estos principios siempre debe determinarse conforme a valoraciones exquisitamente políticas -y como tales reservadas a la discrecionalidad del parlamento-, cfr. ROMANO, Mario, Commentario sistematico del codice penale, vol. I, III ed., Milano: Giuffrè, 2004, Pre-art. $1, \S 53$.
}

${ }^{4}$ DONINI, Il volto attuale, cit. nota $n^{\circ} 3$, p. 72. 
VIGANÒ, Francesco. "La arbitrariedad del no punir. Sobre las obligaciones de tutela penal de los derechos fundamentales".

Relativamente nueva es, en cambio, la pretensión de identificar vínculos positivos a la discrecionalidad del legislador penal, frente a un déficit de protección, por parte del legislador, de intereses que necesitan una tutela penal. No es el exceso de punibilidad, sino la impunidad lo que es asumido aquí como problema.

\subsection{El debate sobre las obligaciones constitucionales de tutela penal y el modelo alemán}

Aquella pretensión, decíamos, es sólo relativamente nueva. En un célebre ensayo de 1982, Domenico Pulitanò recapitulaba los extremos de un debate, entonces actualísimo en Italia y en Alemania, sobre la existencia de obligaciones constitucionales de tutela de algunos bienes jurídicos de relevancia constitucional, entre ellos la vida humana (en relación a la despenalización del aborto, adoptada en los años setenta por el legislador italiano y alemán) y el medioambiente. "No la intervención penal" -escribía lucidamente Pulitanò- "sino que su falta de intervención es lo que viene denunciado como contrario a los principios constitucionales". 6

La respuesta de la Corte constitucional italiana ha sido, sin embargo, categórica: cuestiones de legitimidad sobre esta base son inadmisibles, del momento que, si fueran eventualmente acogidas, el resultado sería en la práctica la creación de un nuevo tipo penal, que el principio de legalidad reserva exclusivamente al legislador. ${ }^{7}$ La situación no ha cambiado radicalmente en los casi treinta años que nos separan de aquel ensayo: es verdad que la Corte ha progresivamente reconocido un propio control sobre las, así llamadas, normas penales favorables, ${ }^{8}$ y cuyos resultados concretos pueden traducirse en una expansión del área aplicable de la normas incriminadoras ya existentes, por efecto de la declaración de ilegitimidad de normas especiales más favorables; pero el presupuesto necesario de este mecanismo sigue siendo la previa criminalización, de parte del legislador, de la tipología general de conductas a las que es reconducible la conducta concreta cometida por el imputado. En cambio, en el caso de un déficit originario de criminalización, la Corte constitucional continúa declarándose incompetente para intervenir: ningún principio constitucional -ni aun el principio de igualdad, que prohíbe discriminaciones irrazonablespodría autorizar a la Corte a colmar las lagunas de punibilidad, extendiendo el ámbito de aplicación de las normas penales preexistentes y de las respectivas sanciones.

La posición estándar de la doctrina penal italiana comparte los resultados a los que la Corte ha arribado, negando de principio la existencia de obligaciones constitucionales de criminalización, con la sola excepción de la obligación (a que se refiere el art. 13 inc. 4

\footnotetext{
5 PULITANÒ, Domenico, “Obblighi costituzionali di tutela penale”, Rivista italiana di diritto e procedura penale (1983), pp. 484-528, pp. 484 y ss.

${ }^{6}$ PULITANÒ, "Obblighi costituzionali", cit. nota $n^{\circ} 5$, p. 485.

${ }^{7}$ En este sentido, cfr. todas las sentencias citadas en aquel trabajo de 1983, p. 490.

${ }^{8}$ A partir de la sent. 148/1983 hasta la reciente sent. 28/2010, sobre la que habrá ocasión de volver brevemente más adelante (cfr. infra, § 3.4). Para una visión general (actualizada al 2006) de la jurisprudencia constitucional en relación al control sobre las normas penales favorables, cfr. MARINUCCI, Giorgio, "Il controllo di legittimità costituzionale delle norme penali: diminuiscono (ma non abbastanza) le "zone franche", Giurisprudenza costituzionale (2006), pp. 4160-4170, pp. 4160 y ss. Cfr. también, en la manualística, PULITANÒ, Domenico, Diritto penale, III ed., Torino: Giappichelli, 2009, pp. 147 y ss.
} 


\section{Polít. crim. Vol. 9, № 18 (Diciembre 2014), Art. 5, pp. 428-476. [http://www.politicacriminal.cl/Vol_09/n_18/Vol9N18A5.pdf]}

Const.) de "punir" la violencia física o moral cometida contra personas privadas de la libertad personal, de la cual podría derivarse la ilegitimidad constitucional de una norma que, en ciertas hipótesis, estableciese una descriminalización de las conductas abarcadas por el art. 608 c.p. (abuso de autoridad contra arrestados y detenidos). ${ }^{9}$ Fuera de esta restringida hipótesis, se sostiene comúnmente que la selección de los intereses merecedores de tutela penal, como también la definición de las conductas punibles y la determinación de las respectivas sanciones, corresponden únicamente al legislador democráticamente elegido, salvo el sucesivo control de parte de la Corte Constitucional sobre la compatibilidad de la legislación penal con los principios constitucionales. ${ }^{10}$ Control, por otro lado, que conservaría siempre un carácter negativo, teniendo como posible salida solamente la invalidez de la elección de criminalización o punición ya realizada por el legislador ordinario en contraposición con cualquier principio constitucional, o sea -a lo más- la invalidación de una norma que arbitrariamente (y por lo tanto además en violación del art. 3 Const.) sustrae determinadas subclases de conductas del ámbito de aplicación de las normas incriminadoras ya previstas de modo general por el legislador. Nunca, por lo tanto, este control podría implicar la creación de un nuevo tipo penal o la agravación del tratamiento sancionatorio, dada - precisamente- la inexistencia de obligaciones, derivadas de la Constitución, de disponer una tutela penal a algún interés diverso de aquel contemplado en el art. 13 inc. 4 Const.

Por otra parte, en el ordenamiento alemán -donde la Corte constitucional ha arribado al resultado opuesto de reconocer la subsistencia de obligaciones constitucionales de tutela penal $^{11}$ - las implicaciones prácticas de tales obligaciones han estado comprendidas dentro de límites muy restrictivos: ellas no conllevan, afirma el Bundesverfassungsgericht, un deber absoluto de punir, sino que por el contrario una mera obligación de activar la amenaza penal (Strafdrohung), quedando entonces en la esfera de la discrecionalidad legislativa la posibilidad de prever causas de no punibilidad a fin de tomar en consideración los contraintereses que entran en juego, siempre que tales causas no impliquen tout court una calificación en términos de licitud de la conducta. ${ }^{12}$

\footnotetext{
${ }^{9}$ Véase el profundo examen del estado del arte realizado por MARINUCCI, Giorgio; DOLCINI, Emilio, Corso di diritto penale, III ed., Milano: Giuffrè, 2001, pp. 501 y ss., como también, más recientemente (y con interesantes indicaciones sobre la doctrina y la jurisprudencia contemporánea relevante de lengua extranjera), PAONESSA, Caterina, Gli obblighi di tutela penale. La discrezionalità legislativa nella cornice dei vincoli costituzionali e comunitari, Pisa: ETS, 2009, pp. 98 y ss.

10 Así, ROMANO, Commentario, cit. nota $\mathrm{n}^{\circ} 3$, Pre-art. 39, § 13 (en parte revisando críticamente una posición expresada con anterioridad en relación a la obligación de tutela -incluso penal- de la vida humana: cfr. ROMANO, Mario; STELLA, Federico, Aborto e legge penale, Riflessioni e proposte, Milano: Giuffrè, 1975, pp. Y 60 ss.). En el mismo sentido, MARINUCCI/DOLCINI, Corso, cit. nota n ${ }^{\circ}$ 9, p. 512.

${ }^{11}$ Así la destacada sentencia BVerfGE 39, 1 ss., p. 45 en materia de aborto, sobre la cual cfr. por todos, ampliamente, PULITANÒ, “Obblighi costituzionali”, cit. nota ${ }^{\circ}$ 5, pp. 491 y ss. La conclusión ha estado, en todo caso, precisada, y en parte redimensionada, en la sucesiva sentencia BVerfGE 88, pp. 203 y ss., también en materia de aborto. Sobre las dos sentencias en referencia, cfr. ampliamente MARINUCCI;/DOLCINI, Corso, cit. nota $\mathrm{n}^{\circ}$ 9, p. 513 ss.

${ }^{12}$ Sobre el estado actual de la doctrina penal alemana en materia de obligaciones constitucionales de tutela penal, cfr., por todos, ROXIN, Claus, Strafrecht. Allgemeiner Teil, vol. I, IV ed., München: Beck, 2006, pp. 43 y ss. (y en el mismo ref. a la doctrina penal y constitucional en la materia). En síntesis, el autor destaca como la Constitución alemana reconoce una obligación de criminalización expresa (en el art. 26 inc. primero)
} 
VIGANÒ, Francesco. "La arbitrariedad del no punir. Sobre las obligaciones de tutela penal de los derechos fundamentales".

\subsection{Las obligaciones supranacionales de tutela penal como obligaciones constitucionales de tutela penal en virtud del artículo 117 inc. 1 de la Constitución italiana}

De mayor impacto práctico aparecen las obligaciones supranacionales de tutela penal: una realidad que aún se esfuerza por alcanzar un lugar en el discusión manualística, pero cuya importancia ha crecido enormemente en las últimas dos décadas.

La pretensión que los legisladores accionen el instrumento penal para proteger determinados intereses proviene, en este caso, de fuentes normativas e instituciones externas respecto al ordenamiento, que vienen así a limitar la discrecionalidad del legislador nacional en la selección de las conductas punibles y en la determinación de la respectiva sanción. El principio de legalidad permanece, por cierto, formalmente respetado, en el sentido que la punición de un determinado imputado continuará a presuponer la existencia de una "ley", en el sentido requerido por el art. 25 inc. 2 Const.; pero la sustancia de tal principio, y su propia ratio como tradicionalmente se ha entendido, sobreviene fuertemente afectada, propiamente por el efecto de la dislocación, del legislador nacional a la instancia supranacional, de la valoración sobre el merecimiento y la necesidad de la pena.

Extremadamente diversa es la tipología de las fuentes supranacionales que imponen obligaciones de penalización al legislador italiano: convenciones multilaterales elaboradas en particular en el ámbito de la ONU, del Consejo de Europa o de otras instituciones, fuentes de la Unión Europea, etc. ${ }^{13}$

Sin embargo, lo que interesa destacar aquí es que estas obligaciones de criminalización, con prescindencia de sus diversos grados de efectividad (que en el caso de los instrumentos internacionales stricto sensu es relativamente baja y es, en cambio, mayor en el caso de los instrumentos de la Unión Europea), deben al mismo tiempo considerarse -desde el punto de vista del derecho italiano-como obligaciones constitucionales de criminalización.

en referencia a los crímenes contra la paz, prescribiendo que tales crímenes deben ser “punidos”. Fuera de esa hipótesis, se sostiene que queda reservado de manera general a la discrecionalidad legislativa establecer si un determinado bien jurídico debe ser tutelado mediante el derecho penal, o si es suficiente una tutela con instrumentos extrapenales, debiendo estos últimos ser privilegiados en cuanto sean igualmente eficaces, en consideración al principio de ultima ratio. Sin embargo, debe reconocerse -al unísono con la Corte constitucional- que el legislador está vinculado a recurrir a la tutela penal de bienes jurídicos fundamentales reconocidos por la Constitución, cuando el deber "positivo" (Schutzpflicht) de tutelar tales bienes jurídicos no pueda ser alcanzado de algún otro modo. En caso contrario -observa Roxin, citando en este sentido a HASSEMER, Winfried, "Strafrechtlicher Rechtsgüterschutz unter der Verfassung", en: Androulakis-FS, Atenas: Ekdoseis Ant. N. Sakkoula, 2003, p. 222- el Estado se sustraería a su esencial tarea de asegurar la pacífica coexistencia entre los ciudadanos. Otra cuestión es, en cambio, aquella de establecer si una obligación similar de tutela penal deba subsistir en relación a la vida humana desde la concepción, como ha sido considerado por la Corte constitucional: cuestión, como es evidente, ampliamente discutida (y en general resuelta en sentido negativo) en la misma doctrina alemana.

${ }^{13}$ Para un cuadro actualizado y detallado de tales obligaciones, y de la respectiva discusión crítica, vid. el reciente trabajo monográfico de PAONESSA, Gli obblighi, cit. nota n ${ }^{\circ}$ 9, pp. 167 y ss. Asimismo, respecto de la doctrina constitucional, BONOMI, Andrea, Il "limite" degli obblighi internazionali nel sistema delle fonti, Torino: Giappichelli, 2008, pp. 314 y ss. 


\section{Polít. crim. Vol. 9, № 18 (Diciembre 2014), Art. 5, pp. 428-476. [http://www.politicacriminal.cl/Vol_09/n_18/Vol9N18A5.pdf]}

De tal consecuencia, a mi entender, no parece haberse enterado nuestra manualística, que, en cambio, continúa negando la existencia de obligaciones constitucionales de tutela penal (más allá de la excepción representada por el art. 13 inc. 4 Const.), incluso después de la trascendental modificación de la jurisprudencia constitucional representada en la sentencias n. 348 y 349, ambas del 2007, las cuales finalmente han dado vigencia al inequívoco tenor literal del art. 117 inc. 1 de la Const.: "la potestad legislativa es ejercitada por el Estado y las Regiones respetando la Constitución, así como los límites derivados del ordenamiento comunitario y de las obligaciones internacionales".

El conjunto de las obligaciones derivadas del derecho de la Unión Europea y del derecho internacional tiene, por lo tanto, fuerza vinculante para el legislador italiano: el cual no puede considerarse autorizado, desde el punto de vista del ordenamiento interno, para incumplir sus propias obligaciones internacionales, sino que está obligado a cumplir con ellas en el ejercicio de la potestad legislativa, a menos que las obligaciones supranacionales en cuestión, a su vez, resulten incompatibles con las normas constitucionales o -en lo que concierne a las obligaciones derivadas del derecho de la Unión Europea- con los "principios superiores del ordenamiento italiano": principios, por otra parte, hasta ahora nunca identificados por la Corte constitucional. ${ }^{14}$

\subsection{En particular, las obligaciones supranacionales de tutela de los derechos fundamentales}

El objeto preciso de este estudio es, sin embargo, la específica tipología de límites a la discrecionalidad legislativa en materia penal, elaborados en sede supranacional y derivados directamente de las razones de tutela de los derechos fundamentales de la persona. La idea de fondo es, por ende, que una protección eficaz de por lo menos algunos de los derechos humanos frente a las agresiones más graves pasa necesariamente por el derecho penal; y que los Estados están obligados, desde el punto de vista del derecho internacional, a prever (y concretamente a asegurar) esa tutela en el ámbito de los respectivos ordenamientos internos. $^{15}$

Esta lógica está en la base del derecho penal internacional. Su palabra clave, que ha inspirado la creación de los tribunales ad hoc y después la propia Corte penal internacional, es precisamente la lucha contra la impunidad: ${ }^{16}$ contra la impunidad de los genocidios, así como contra los crímenes de guerra y contra la humanidad, que ofenden los más básicos de los derechos humanos en los contextos de guerra y de violaciones sistemáticas a gran escala. La preocupación dominante, aquí, es aquella de asegurar que los responsables de

\footnotetext{
${ }^{14}$ Otra y distinta cuestión es aquella de establecer si, y eventualmente en qué medida, la Corte constitucional pueda sancionar las violaciones por parte del legislador de las obligaciones de criminalización derivadas de las fuentes supranacionales. Para algunas consideraciones sobre el punto, cfr. infra, § 3.4.

${ }^{15}$ Cfr., sobre el tema, SANTANA VEGA, Dulce Maria, "Diritto penale minimo e obblighi costituzionali taciti di tutela penale", Dei delitti e delle pene, 2000, p. 47-67; PAONESSA, Gli obblighi, cit. nota n ${ }^{\circ} 9$, pp. 98 y ss.

${ }^{16}$ En el preámbulo del Estatuto de la Corte penal internacional se observa, de hecho, que "los crímenes más graves de trascendencia para la comunidad internacional en su conjunto no deben quedar sin castigo", y que los Estados partes están "decididos a poner fin a la impunidad de los autores de esos crímenes y a contribuir así a la prevención de nuevos crímenes".
} 
VIGANÒ, Francesco. "La arbitrariedad del no punir. Sobre las obligaciones de tutela penal de los derechos fundamentales".

tales violaciones respondan penalmente de sus acciones; y la intervención de la jurisdicción penal está pensada, en la fase actual de maduración del desarrollo del derecho penal internacional reflejada en el Estatuto de Roma, como meramente subsidiaria para las hipótesis en las cuales el Estado donde se han verificado esas violaciones no pueda o no quiera ejercitar directamente la potestad punitiva. No es, por lo mismo, casualidad que del Estatuto de Roma deriven obligaciones de persecución penal de los responsables a cargo de los Estados miembros, ${ }^{17}$ lo cual presupone lógicamente la subsistencia de las correspondientes incriminaciones, en cuyo eventual incumplimiento es llamada a suplir la Corte penal internacional en razón del, así llamado, principio de complementariedad. ${ }^{18}$

La lógica según la cual una tutela "efectiva" de los derechos humanos exige la punición de los responsables de dichas violaciones, se ha extendido, sin embargo, más allá de los excepcionales contextos en los que hasta ahora ha operado el derecho penal internacional. Ello por efecto de al menos dos fenómenos distintos, si bien convergentes.

Por un lado, desde finales de los años cuarenta, han surgido una serie de instrumentos convencionales que imponen obligaciones de criminalización de conductas lesivas de derechos fundamentales de la persona. Estas obligaciones se encuentran en la Convención de la ONU sobre genocidio de 1948 y en la coetánea Convención de Ginebra de 1949, y también -para limitarnos a un par de ejemplos-en la Convención suplementaria de Ginebra de 1956 sobre la esclavitud y prácticas análogas, en la Convención internacional sobre la eliminación de todas las formas de discriminación racial de 1965, en la Convención ONU contra la tortura del 1984, llegando hasta textos recientes como el Protocolo facultativo de la Convención sobre los derechos del niño relativos al tráfico de menores, la prostitución y la pornografía infantil del 2000 y los correspondientes instrumentos adoptados en el seno del Consejo de Europa y de la Unión Europea.

Por otra parte -siendo éste el fenómeno más interesante, sobre el cual intento llamar la atención en las páginas siguientes- obligaciones no sólo de criminalización, sino que propiamente de efectiva punición de conductas lesivas de derechos fundamentales, han comenzado a ser desarrolladas en las últimas dos décadas por la jurisprudencia paralela de las dos cortes 'regionales' de derechos humanos -la Corte Interamericana de San José y el Tribunal Europeo de Estrasburgo.

Ni la Convención interamericana ni el Convenio europeo, como se sabe, establecen alguna obligación explícita de tutela penal de los derechos humanos en ellas reconocidos, limitándose a establecer, en sus respectivos artículos primeros, el deber de todos los Estados partes de "reconocer" (o "asegurar", en la versión inglesa de la Convención europea) tales derechos. Sin embargo, como veremos con mayor detenimiento cuando analicemos el notable desarrollo de las dos jurisprudencias en la materia, las dos Cortes han

\footnotetext{
${ }^{17}$ En el preámbulo del Estatuto se indica que “es deber de todo Estado ejercer su jurisdicción penal contra los responsables de crímenes internacionales".

18 Sobre esto cfr. por todos, en la literatura italiana, FRONZA, Emanuela, Il principio di complementarità, esercizio delle giurisdizione e adeguamento a livello interno, en: AMATI, Enrico et. al. (Eds.), Introduzione al diritto penale internazionale, Milano: Giuffrè, 2006, pp. 35 y ss.
} 
inferido por vía interpretativa la existencia de obligaciones a cargo de los Estados partes no solamente de incriminar las conductas más gravemente ofensivas de los más fundamentales entre los derechos humanos reconocidos en las respectivas convenciones, sino que incluso de perseguir y de punir a los responsables con sanciones proporcionadas a la gravedad de la violación. La obligación que en tal sentido viene afirmada no es así limitada -según el modelo adoptado por la Corte constitucional alemana, al que nos hemos referido antes- a la amenaza de una pena prevista en una norma incriminadora; sino que se extiende a la efectiva aplicación de la pena en el caso concreto, y de una pena suficientemente severa para representar una eficaz disuasión contra eventuales futuras violaciones al derecho en cuestión.

Incluso aquí la expresión clave -explicitada exactamente en estos términos en la jurisprudencia de la Corte de San José- es aquella de lucha contra la impunidad, que implica también la prohibición dirigida a las legislaciones nacionales de prever causas de exención de la pena privativa de libertad (incluso sea con el mecanismo de la suspensión condicional) o, a fortiori, causales de no punibilidad -comprendiendo las amnistías y prescripciones- en favor de los autores de violaciones que, según la apreciación de las dos Cortes, son de tan relevancia que no pueden ser sancionadas sino con el arma de la pena.

El razonamiento común a estas dos jurisprudencias es, por otra parte, que las investigaciones penales, el proceso y la pena impuesta al responsable son asumidos en su conjunto como instrumento reparador para la víctima de la violación, la cual -afirma la Corte interamericana- tiene un preciso derecho a la verdad, asegurado mediante las investigaciones y el proceso penal.

Similar desarrollo importa una autentica inversión del rol tradicionalmente atribuido a los derechos humanos respecto al derecho penal: desde siempre concebidos como límites garantísticos opuestos al ejercicio de la potestad punitiva estatal, los derechos humanos se convierten aquí en razones que reclaman la intervención del derecho penal. ${ }^{19}$ Desde la perspectiva de la tutela de los derechos humanos contra el derecho penal se pasa a la prospectiva de los derechos humanos como objeto necesario de la tutela penal; y el acento se ubica desde los derechos del acusado y del condenado-objetos tradicionales de la tutela de las cartas constitucionales, y de las propia cartas internacionales de derechos humanosa los derechos de la víctima de las violaciones.

\subsection{La relevancia práctica de la cuestión}

Lo antes dicho obliga a reflexionar sobre esta cuestión con una aproximación libre de prejuicios y dogmatismos.

\footnotetext{
${ }^{19}$ Ya a finales de los años ochenta DELMAS-MARTY, Mireille, "Politica criminale e diritti dell'uomo in Europa”, Indice penale, año XXII, no 2 (1988), pp. 205-216, p. 822 había destacado la doble naturaleza limitativa y propulsiva - del discurso sobre los derechos humanos en relación al derecho penal. Cfr. también ID., Dal codice penale ai diritti dell'uomo, Milano: Giuffrè, 1992, pp. 265 y ss.
} 
VIGANÒ, Francesco. "La arbitrariedad del no punir. Sobre las obligaciones de tutela penal de los derechos fundamentales".

La experiencia americana -a la cual será dedicada el próximo parágrafo- muestra como la perspectiva de la existencia de obligaciones de tutela penal de los derechos fundamentales se ha ido imponiendo en el transcurso de pocos años, con consecuencias literalmente explosivas: centenares de procesos contra los responsables de violaciones a los derechos humanos cometidas durante las sangrientas dictaduras de los años setenta y ochenta han sido reabiertos, no obstante la existencia de leyes de amnistía e -incluso- de sentencias absolutorias con fuerza de cosa juzgada. Más aún, muchos de esos responsables, que habían confiado en la impunidad que ellos mismos se habían garantizado mediante esas leyes de amnistía, se encuentran hoy presos, precisamente por efecto de la jurisprudencia de la Corte interamericana, asumida hoy por las máximas jurisdicciones nacionales como vinculante.

Mas se equivocaría quien, desde Europa, observara estos fenómenos con la mirada distante del comparatista. Día a día crece en los jueces italianos, ordinarios y constitucionales, la influencia de la jurisprudencia de Estrasburgo, la cual comparte hoy día todas las premisas conceptuales de la homóloga jurisprudencia de San José; y, verosímilmente, no tardará el Tribunal de Estrasburgo en dictar condenas, incluso sobre el Estado italiano, por no haber dispuesto una adecuada tutela penal a la víctima de violaciones de derechos convencionales.

Pienso en los graves acontecimientos de Génova de 2001, donde se cometieron por la policía italiana hechos inequívocamente calificables como tortura y/o tratamientos inhumanos y degradantes, los cuales - sin embargo- no pudieron ser sancionados porque prescribieron antes de la dictación de una sentencia definitiva de condena; y esto por la falta de previsión, en el ordenamiento italiano, de una norma incriminadora ad hoc del delito de tortura, provista de una adecuada penalidad abstracta, en grado de escapar del filo de los plazos de prescripción modificados por la ley n. $251 / 2005 .{ }^{20}$ Un caso evidente de impunidad, que está ahora pendiente frente al Tribunal de Estrasburgo y que acabará con toda probabilidad en una condena del Estado italiano, por no haber castigado los autores de violaciones del derecho reconocido por el artículo $3 \mathrm{CEDH}$.

Frente a estos desarrollos, surgen -inmediatas e inquietantes- algunas preguntas. ¿Es legítimo ese cambio de paradigma en la relación entre los derechos humanos y el derecho penal? ¿No hay aquí un riesgo de distorsión de las funciones modernamente atribuidas a la pena, con una perniciosa recaída en concepciones arcaicas de la pena como instrumento de venganza privada? ¿Y es admisible que un puñado de jueces internacionales, desprovistos de toda legitimación democrática, puedan prohibir a los legisladores instituir áreas de no punibilidad en favor de los autores de las violaciones a los derechos fundamentales de la víctima?

\footnotetext{
${ }^{20}$ Sobre los dos acontecimientos, vid. el denso ensayo de COLELLA, Angela, "C'è un giudice a Strasburgo. In margine alle sentenze sui fatti della Diaz e di Bolzaneto: l'inadeguatezza del quadro normativo attuale in tema di repressione penale della tortura", Rivista italiana di diritto e procedura penale (2009), pp. 1801-1843 pp. 1801 y ss.
} 
Polít. crim. Vol. 9, № 18 (Diciembre 2014), Art. 5, pp. 428-476.

[http://www.politicacriminal.cl/Vol_09/n_18/Vol9N18A5.pdf]

\section{La "lucha contra la impunidad" en la jurisprudencia interamericana}

\subsection{La fundamentación teórica de las obligaciones de ciertos derechos fundamentales según la Corte de San José de Costa Rica}

Para intentar dar una respuesta a estas preguntas, tendremos que profundizar un poco más la jurisprudencia de las Cortes homólogas de Estrasburgo y San José en materia de obligaciones de tutela penal. Y, ya que los resultados más interesantes respecto del punto han sido desarrollados por la Corte interamericana, conviene iniciar el análisis a partir de los pronunciamientos de esta última. ${ }^{21}$

Desde finales de los noventa la jurisprudencia de la Corte de San José ha asumido entre sus tareas fundamentales la de "combatir con todos los medios legales disponibles [...] la impunidad" por las violaciones de los más fundamentales ${ }^{22}$ entre los derechos reconocidos en la Convención Americana de Derechos Humanos (en adelante, "CADH"): la vida, el derecho a no ser sometidos a torturas y tratamientos inhumanos o degradantes, la libertad personal. Y esto en cuanto la impunidad -definida expresamente como "la falta en su conjunto de investigación, persecución, captura, enjuiciamiento y condena de los responsables de las violaciones de los derechos protegidos por la Convención"- "propicia la repetición crónica de las violaciones de derechos humanos y la total indefensión de las víctimas y de sus familiares". 23

Existe por lo tanto, según la Corte, un preciso deber a cargo de los Estados partes de la Convención de desarrollar las investigaciones sobre las agresiones a los derechos humanos sufridas por las víctimas y/o sus familiares; de individualizar en cuanto sea posible a los responsables; de ponerlos a disposición de la justicia; de juzgarlos en un proceso penal; y, por último, de sancionarlos con la pena apropiada.

Ninguna norma de la Convención, por cierto, establece expresamente tales deberes a cargo de los Estados. Sin embargo, la Corte sostiene que ellos derivan de un conjunto de prescripciones convencionales: del art. $1 \S 1$, que sanciona la obligación a cargo de los Estados de "respetar" los derechos y la libertad reconocidos en la Convención, y de "garantizar" su libre y pleno ejercicio; del art. 2, que impone a todos los Estados adecuar sus ordenamientos jurídicos internos a las obligaciones procedentes de la Convención; del

${ }^{21}$ El análisis contenido en este parágrafo profundiza aquella desarrollada por el suscrito en "Droits de l'homme et droit pénal: Un hommage à Sergio García Ramírez”, Cahiers de défense sociale, 2009-2010, pp. 83-93.

${ }^{22}$ En sentido crítico sobre la vaguedad de tal delimitación, cfr. MALARINO, Ezequiel, "Il volto repressivo della recente giurisprudenza argentina sulle gravi violazioni dei diritti umani”, en: FRONZA, Emanuela; FORNASARI, Gabriele (Eds.), Il superamento del passato e il superamento del presente, Trento: Università di Trento Ed., 2009, p. 46, en el contexto de una inteligente y profunda contribución (publicada también en español, con abundante cantidad de citas, en Jura Gentium, V (2009), accesible online en la página web www.juragentium.unifi.it).

${ }^{23}$ Las citas textuales son sacadas literalmente de la Corte IDH, Paniagua Morales et. al., sent. 8 de marzo de 1998, § 173. En el mismo sentido cfr. también la sentencia de la Corte IDH, Castillo Páez c. Perú, sent. 27 de noviembre de 1998 (reparación y costas), § 107, como también Loayza Tamayo c. Perú, sent. 27 noviembre de 1998 (reparaciones y costas), $\S 170$. 
VIGANÒ, Francesco. "La arbitrariedad del no punir. Sobre las obligaciones de tutela penal de los derechos fundamentales".

artículo $8 \S 1$, que reconoce, en el ámbito de la garantías del "debido proceso", el derecho a ser oído por un juez imparcial; y, por último, del art. 25, que reconoce el derecho a un recurso efectivo para la tutela de los derechos convencionales en frente de una autoridad jurisdiccional interna. ${ }^{24}$

Es evidente el carácter fuertemente creativo de esta jurisprudencia de la Corte, que no se preocupa de motivar desde el punto de vista textual los resultados innovadores -y ciertamente no previstos por los redactores de la Convención, ni por los Estados partes al momento de las ratificaciones- a los cuales arriba. ${ }^{25}$ Desde el punto de vista del observador europeo, es interesante subrayar la referencia a la obligación general a cargo de los Estados partes de "respetar" los derechos y las libertades reconocidas en la Convención, que -como veremos- aparece también en la jurisprudencia de Estrasburgo sobre las obligaciones de tutela penal, como también las dos referencias a los art. $8 \S 1$ y 25 , que proyectan una luz importante sobre la ratio de las obligaciones individualizadas por la Corte.

La ratio de estas referencias reside en la evidente funcionalización de la tutela penal de los derechos fundamentales (comprensiva de las investigaciones, del proceso y de la determinación y ejecución de la pena) a los intereses de la víctima de las violaciones. En este sentido se aprecia, en primer lugar, la mención del derecho a un recurso efectivo, con la cual se evoca evidentemente la idea de la tutela penal, en el sentido amplio que se ha expresado, como forma de reparación a la víctima; así como la referencia -del todo original en la óptica europea- al derecho a ser oído por un juez imparcial, ${ }^{26}$ que el observador europeo tiende instintivamente a asociar a la posición del imputado, y que en ese contexto es entendido - una vez más- como derecho de la víctima de la violación. Esto revela una concepción del proceso penal no sólo como instrumento de garantía para el imputado, sino también como lugar ofrecido por el ordenamiento a la víctima o a sus familiares para hacer sentir su propia voz, en clave lato sensu reparatoria de la injusticia sufrida.

En esta misma óptica se ubica la insistencia de la Corte respecto del derecho a la verdad ${ }^{27}$ -aunque carente de explicita base textual- del cual la víctima de la violación es reconocida titular, y cuya satisfacción es confiada a la ejecución de investigaciones diligentes por parte

\footnotetext{
${ }^{24}$ Para una enumeración orgánica de tales disposiciones convencionales, cfr. en especial la propia Corte IDH, Barrios Altos c. Perú, sent. 14 de marzo 2001 (mérito), § 42 y ss.

${ }^{25}$ El punto es destacado con particular vigor -en un contexto en general fuertemente crítico en relación con esta jurisprudencia de la Corte- por MALARINO, "Il volto repressivo", cit. nota n²2, pp. 67 y ss.

${ }^{26}$ En este respecto, cfr. Corte IDH, Castillo Páez c. Perú, cit. nota n ${ }^{\circ} 23, \S 106$.

${ }^{27}$ Corte IDH, Barrios Altos c. Perú, cit. nota n ${ }^{\circ} 24, \S 47$ y s. Además, en el caso Castillo Páez c. Perú, sent. 3 de noviembre de 1997 (mérito), § 90, la Corte ya se había referido a un "derecho de los familiares de la víctima de conocer cuál fue el destino de ésta y, en su caso, dónde se encuentran sus restos". Para una reflexión crítica sobre el concepto mismo de "derecho a la verdad" y su justiciabilidad mediante los instrumentos del proceso penal, cfr. PASTOR, Daniel, "Processi penali solo per conoscere la verità? L'esperienza argentina”, en: FRONZA/FORNASARI (Eds.), Il superamento del passato, cit. nota n 22, p. 99 ss. (N.T.: publicado en español en “¿Procesos penales sólo para conocer la verdad? La experiencia argentina”, Revista Jueces para la Democracia n. 59 (2007), pp. 95-126)
} 
del Estado, y al sucesivo proceso penal contra quienes hayan sido individualizados como posibles autores.

La función reparadora asignada a las investigaciones y al proceso, como también a la captura de los sospechosos y a la condena de quienes sean reconocidos como responsables, emerge precisamente del tenor de las decisiones sobre las "reparaciones" reconocidas por la Corte a la víctimas en el sentido del art. 63 de la Convención. La reparación, lejos de estar confinada a una indemnización de naturaleza pecuniaria (como normalmente sucede en la jurisprudencia del Tribunal de Estrasburgo), se extiende regularmente -en las tipologías de casos que aquí se examinan- al pronunciamiento de una obligación, a cargo del Estado, de abrir o, si es del caso, reabrir las investigaciones sobre las violaciones sufridas por el recurrente, con la finalidad de «identificar y sancionar a los responsables», previa la adopción de "todas las disposiciones necesarias en el derecho interno para asegurar la ejecución de esta obligación". 28

\subsection{Las implicaciones prácticas de esta jurisprudencia}

Prosiguiendo en este sendero, la Corte interamericana ha llegado a declarar la contrariedad a la Convención de las, así llamadas, leyes de "autoamnistía": ${ }^{29}$ es decir, de leyes de amnistía emanadas por los detentadores del poder en favor de ellos mismos y de sus seguidores, bajo el pretexto de la "pacificación nacional" después de periodos de graves turbulencias. Ejemplos de amnistías similares abundan, no solo en el continente americano, sino también en la historia alemana e italiana en el siglo pasado. ${ }^{30}$ Según la Corte, tales leyes:

“(...)son manifiestamente incompatibles con la letra y el espíritu de la Convención Americana. Este tipo de leyes impide la identificación de los individuos responsables de violaciones a derechos humanos, ya que se obstaculiza la investigación y el acceso a la justicia e impide a las víctimas y a sus familiares conocer la verdad y recibir la reparación correspondiente." 31

De tal incompatibilidad desciende, en opinión de la Corte, la radical invalidez, incluso en el contexto de los ordenamientos jurídicos internos, de las leyes en cuestión, ${ }^{32}$ que deben ser

\footnotetext{
${ }^{28}$ Así al menos a partir de la sentencia sobre reparaciones y costas en el caso Castillo Páez c. Perú, de cuyo dispositivo se extraen las expresiones entre comillas.

${ }^{29}$ Para esta definición, cfr. el voto concurrente del juez García Ramírez en el caso Castillo Páez c. Perú, cit. nota $\mathrm{n}^{\circ} 23$, § 9. Sobre la ilegitimidad de la amnistía emanada del detentador del poder en favor de si mismo, deducida del principio de "prohibición de auto favorecimiento" (Verbot der Selbstbegünstigung), cfr. en la literatura alemana MARXEN, Klaus, Rechtliche Grenzen der Amnestie, Heidelberg: Müller Verl., 1984, p. 38 ss. Sobre el tema, cfr. además, en la literatura italiana, las agudas observaciones de MAIELLO, Vincenzo, Clemenza e sistema penale, Napoli: ESI, 2007, pp. 414 y ss.

${ }^{30}$ Cfr. una serie de ilustradores ejemplos en MAIELLO, Clemenza, cit. nota ${ }^{\circ} 29$, pp. 248 y ss.

${ }^{31}$ Así, la Corte IDH, Barrios Altos c. Perú, cit. nota n 24, § 43.

${ }^{32}$ Así, en particular, el voto concurrente del juez García Ramirez en el caso Barios Altos c. Perú, cit. nota $n^{\circ}$ $24, \S 15$, donde se destaca que la incompatibilidad con las obligaciones convencionales de las leyes de "autoamnistía" promulgadas por el Estado peruano trae consigo la invalidez de aquellas leyes, "en cuanto pugnan con los compromisos internacionales del Estado. Por ello, no pueden producir los efectos jurídicos
} 
consecuentemente desaplicadas por los jueces nacionales, los cuales - como todos los otros órganos y poderes del Estado- están igualmente vinculados al respeto de las obligaciones derivadas de la Convención, así como interpretadas por la misma Corte de San José. ${ }^{33}$

Por otra parte, la Corte ha señalado que la obligación de investigar y procesar a los responsables de las violaciones a derechos humanos no podrá eludirse por efecto de la prescripción -por lo menos en relación a los crímenes que deben considerarse imprescriptibles, según el ius cogens internacional, como la tortura, las ejecuciones sumarias, extralegales o arbitrarias, o incluso las desapariciones forzadas-. Tampoco podrán legítimamente (desde el punto de vista de la Convención) ser previstas, por parte del legislador penal interno, causas eximentes en relación a similares violaciones. ${ }^{34}$

Aún más: tampoco la potestad punitiva estatal -y el correspondiente deber, derivado de la Convención, de investigar y de ejercer la acción penal contra los responsables de las violaciones- podrá considerarse paralizada por la excepción de cosa juzgada: la misma garantía del ne bis in idem, que está expresamente reconocida por la Convención en el art. 8.4, no podrá en efecto operar en presencia de una sentencia de absolución meramente aparente, o incluso fraudulenta, como aquella que resulta de un proceso celebrado con el sólo fin real de mantener la impunidad del crimen y de su autor. ${ }^{35}$

La obligación a cargo del Estado de asegurar la efectiva punición de los responsables no podrá eludirse ni siquiera cuando un Estado, que deja atrás un periodo de grave conflictividad interna, instituya comisiones de reconciliación y justicia, con la finalidad de

inherentes a normas legales expedidas de manera regular y compatibles con las disposiciones internacionales y constitucionales que vinculan al Estado peruano. La incompatibilidad determina la invalidez del acto, y ésta implica que dicho acto no pueda producir efectos jurídicos". Más sintéticamente, en la misma sentencia se afirma (\$44) que las leyes de autoamnistía en cuestión "carecen de efectos jurídicos y no pueden seguir representando un obstáculo para la investigación de los hechos que constituyen este caso ni para la identificación y el castigo de los responsables".

${ }^{33}$ Tal consecuencia, ya implícita en los pasajes de la sentencia y del voto concurrente de García Ramirez en el caso Barrios Altos, señalados en la nota precedente, se expresa claramente en la sentencia de la Corte IDH, Almonacid Arellano y otros c. Chile, sent. del 26 de septiembre de 2006, § 121-124, donde la Corte precisa que la promulgación y el mantenimiento en vigor de leyes de "autoamnistía" representan per se una violación del deber, impuesto del art. 2 de la Convención, de conformar el ordenamiento interno a las obligaciones convencionales, agregando ( $§ 123)$ que "cuando el Legislativo falla en su tarea de suprimir y/o no adoptar leyes contrarias a la Convención Americana, el Judicial permanece vinculado al deber de garantía establecido en el artículo 1.1 de la misma y, consecuentemente, debe abstenerse de aplicar cualquier normativa contraria a ella. El cumplimiento por parte de agentes o funcionarios del Estado de una ley violatoria de la Convención produce responsabilidad internacional del Estado". Y además (§ 124): "En otras palabras, el Poder Judicial debe ejercer una especie de "control de convencionalidad" entre las normas jurídicas internas que aplican en los casos concretos y la Convención Americana sobre Derechos Humanos. En esta tarea, el Poder Judicial debe tener en cuenta no solamente el tratado, sino también la interpretación que del mismo ha hecho la Corte interamericana, intérprete última de la Convención Americana". En el caso La Cantuta c. Perú, sent. del 29 de noviembre de 2006, § 177, la Corte incluso llega a estimar preferible la solución de la desaplicación de la leyes de autoamnistía por parte del poder judicial por sobre su derogación por parte del legislador, pues ésta última no tendría efecto retroactivo e implicaría, más bien, un implícito reconocimiento de la validez de las leyes derogadas.

${ }^{34}$ Así, la Corte IDH, Barrios Altos, sent. 14 de marzo de 2001 (mérito), § 41.

${ }^{35}$ Corte IDH, Almonacid Arellano, cit. nota ${ }^{\circ} 33, \S 154$. 


\section{Polít. crim. Vol. 9, № 18 (Diciembre 2014), Art. 5, pp. 428-476. [http://www.politicacriminal.cl/Vol_09/n_18/Vol9N18A5.pdf]}

arrojar luces sobre el pasado con vistas a una reconciliación nacional. Al menos las violaciones macroscópicas de derechos humanos -tras las cuales se incluyen ciertamente los crímenes contra la humanidad, según las definiciones de derecho penal internacionaldeberán necesariamente ser perseguidas penalmente, para garantizar tutela a las víctimas, y para enviar un mensaje de clara advertencia a posibles futuros autores. ${ }^{36}$

\subsection{Los (explosivos) efectos sobre los ordenamientos internos}

Como se acaba de mencionar, esta jurisprudencia ha sido íntegramente recogida por las jurisdicciones internas de importantes estados de América del Sur. Entre ellos, Perú, ${ }^{37}$ Chile $^{38}$ y Argentina.

Emblemático, en este punto, es el ejemplo argentino. En el caso Simón, del 2005, la Corte Suprema de ese país declaró inválidas e inconstitucionales las dos leyes de amnistías aprobadas por el Parlamento en 1987, en nombre de la pacificación nacional, cuatro años después del término de la dictadura militar; y, en consecuencia, provocó la reapertura generalizada de varias decenas de investigaciones y procesos penales en contra de todos los responsables de los "crímenes de lesa humanidad" cometidos en el país entre los años 1976 y $1983 .{ }^{39}$ La Corte justificó tal resultado apoyándose esencialmente ${ }^{40}$ sobre la mencionada jurisprudencia de la Corte interamericana (por su parte dictada en relación a controversias concernientes a otros Estados); ${ }^{41}$ jurisprudencia, esta última, considerada vinculante incluso para el ordenamiento argentino, sea en razón del art. 75 inc. 22 de la Constitución, que atribuye rango constitucional a determinados tratados internacionales en materia de

\footnotetext{
${ }^{36}$ Corte IDH, Almonacid Arellano, cit. nota ${ }^{\circ} 33, \S 150$.

${ }^{37}$ Para puntuales referencias sobre la desaplicación, en Perú, de la ley de amnistía ya objeto de los casos Castillo Páez, Loayza Tamayo y Barrios Altos, cit. notas 23 y 24, cfr. Corte IDH, La Cantuta, cit. nota $n^{\circ} 33$, $\S 177$ ss.

${ }^{38}$ Referencias puntuales en Corte IDH, Almonacid Arellano, cit. nota ${ }^{\circ} 33, \S 72$.

${ }^{39}$ Corte Suprema de Justicia de la Nación Argentina, Simón, sent. del 14 de junio de 2005. Para una detallada reconstrucción de los intrincados eventos jurídicos y políticos-institucionales desarrollados entre 1983 y la actualidad, en relación a la persecución penal de los crímenes cometidos durante la dictadura militar, cfr. PARENTI, Pablo, "La persecuzione penale di gravi violazioni dei diritti umani in Argentina", en: FRONZA/FORNASARI (Eds.), Il superamento del passato, cit. nota $\mathrm{n}^{\circ} 22$, pp. 13 y ss. (N.T. publicado en español en Cuadernos de doctrina y jurisprudencia penal $\mathrm{n}^{\circ}$ 9, 2003). Véase también -más sintéticamenteMALARINO, "Il volto repressivo", cit. nota n²2, pp. 31 y ss.

${ }^{40}$ Sobre la intrínseca debilidad de una segunda línea argumentativa utilizada por la Corte argentina (orientada a demostrar la contrariedad de las leyes de amnistía concernientes a los crímenes contra la humanidad a los principios del derecho penal internacional, a los cuales la Argentina debe también considerarse vinculada), cfr. MALARINO, "Il volto repressivo", cit. nota n 22, pp. 75 y ss.

${ }^{41} \mathrm{Y}$ en particular sobre la base de los principios enunciados en el caso Barrios Altos c. Perú, ampliamente citado en el parágrafo precedente. Sobre la problemática de la importación al interno de un Estado de principios desarrollados por la Corte interamericana en relación a terceros Estados, respecto a lo dispuesto en el art. 68 de la Convención (correspondiente al art. $46 \S 1 \mathrm{CEDH}$ ) que sanciona la obligatoriedad de las sentencias de la Corte solo para los Estados que han sido partes de la controversia, cfr. MALARINO, "Il volto repressivo", cit. nota n $^{\circ} 22$, pp. 49 y ss. El autor subraya por lo demás que -en el caso sub iudice- la Corte argentina aplicó principios enunciados por la Corte interamericana en sede de ratificación de un acuerdo amistoso entre la Comisión interamericana recurrente y el Estado peruano, en el cual este último se había espontáneamente comprometido a considerar invalidas las leyes de amnistía dictadas en favor de los anteriores detentadores del poder.
} 
derechos humanos "en las condiciones de su vigencia"; ${ }^{42}$ sea simplemente en relación al deber, puesto a cargo del poder judicial argentino, de evitar exponer al Estado a una responsabilidad internacional por las violaciones a las obligaciones convencionales. ${ }^{43}$

Esta historia, decíamos, es emblemática, porque -como ha destacado la doctrina más crítica en frente a la jurisprudencia en cuestión, así como la única opinión disidente en el mismo caso Simón- las leyes de amnistía de Argentina, declaradas inválidas e inconstitucionales por la Corte Suprema de Buenos Aires, no podían, en rigor, ser consideradas leyes de "autoamnistía" en el sentido utilizado por la misma Corte interamericana, habiendo sido aprobadas tras un debate parlamentario transparente años después de la transición democrática, y a partir de una ponderación de intereses que condujo a privilegiar la perspectiva de la pacificación nacional por sobre los intereses de la persecución penal de los crímenes cometidos en el pasado reciente por la dictadura militar. ${ }^{44}$

El caso Simón pone claramente en evidencia la capacidad de penetración en el ordenamiento interno de la jurisprudencia de la Corte interamericana en materia de tutela penal de los derechos fundamentales: con el riesgo asociado que tal jurisprudencia -de por si problemática en cuanto a su pretensión de limitar severamente la discrecionalidad del legislador democrático en la elección de no punir-produzca, en los ordenamientos internos, resultados aun más radicales de aquellos que la misma Corte, probablemente, tenía en mente. $^{45}$

${ }^{42}$ Sobre la problemática de tal inciso, que -con referencia específica a la Convención americana- podría aludir sea a la condiciones de vigencia del instrumento internacional en el ordenamiento nacional (en relación a la reserva hecha por el Estado argentino al momento de la ratificación del tratado), sea-como en cambio lo ha considerado la Corte Suprema - al rol de interprete 'autentico' del instrumento asignado a la Corte de San José, cfr. vid. con profundidad, MALARINO, "Il volto repressivo", cit. nota n ${ }^{\circ} 22$, pp. 52 y ss. Conviene, por otra parte, recordar como, antes de la introducción -en el 1994- de la norma constitucional en comento, la Corte Suprema ya había asignado a los tratados internacionales vinculantes para el Estado argentino un rol superior respecto a las leyes ordinaria, aunque subordinado respecto de la Constitución (Corte Suprema de Justicia de la Nación argentina, Ekmekdjian c. Sofovich, sent. del 7 de julio de 1992): con una solución, por lo tanto, sustancialmente coincidente con aquella adoptada por la Corte constitucional italiana en la sentencia $\mathrm{n}$. 348 y $349 / 2007$.

${ }^{43}$ Este argumento se hace eco, evidentemente, de aquel utilizado por la Corte interamericana y del cual se ha dado cuenta en el parágrafo anterior, según el cual -en el plano del derecho internacional- las obligaciones derivadas de la Convención, como interpretadas por la Corte interamericana, vinculan directamente a todos los órganos y poderes del Estado miembro, incluyendo el poder judicial. Esta afirmación es también recurrente en la jurisprudencia del Tribunal EDH (cfr., sobre este punto, VIGANÒ, Francesco, "Il giudice penale e l'interpretazione conforme alle norme sopranazionali", en: CORSO, Piermaria; ZANETTI, Elena, Studi in onore di Mario Pisani, vol. II, Piacenza: La Tribuna, 2010, pp. 641 y ss.)

${ }^{44}$ MALARINO, "Il volto repressivo", cit. nota n ${ }^{\circ} 22$, pp. 70 y ss., donde se destaca igualmente como las leyes en cuestión ya habían sido consideradas conformes a la Constitución, en 1987, por la misma Corte Suprema argentina.

${ }^{45}$ Es necesario, de hecho, ser cautelosos en relación a la temática especifica de la amnistía. En el influyente voto concurrente en el caso Castillo Páez, cit. nota ${ }^{\circ} 23, \S 9$ y después literalmente reiterado en el propio voto concurrente en el caso sucesivo Barrios Altos, cit. nota ${ }^{\circ} 24$, § 10, el juez García Ramírez se hizo cargo de distinguir la "autoamnistía" -en su opinión ilegitima en relación a la Convención, y por consecuencia invalida respecto de los ordenamientos internos de los Estados partes- de las legítimas amnistías "que resultan de un proceso de pacificación con sustento democrático y alcances razonables". Por otra parte, en la misma opinión se expresa la advertencia que ni siquiera esta tipología de amnistía pueda concurrir a la total 
Polít. crim. Vol. 9, № 18 (Diciembre 2014), Art. 5, pp. 428-476.

[http://www.politicacriminal.cl/Vol_09/n_18/Vol9N18A5.pdf]

\section{La paralela jurisprudencia del Tribunal europeo}

\subsection{La progresiva determinación de las obligaciones de tutela penal en la jurisprudencia de Estrasburgo}

A resultados similares -aunque, por ahora, con mucho menor impacto sobre los ordenamientos internos de los Estados miembros- ha arribado, del otro lado del océano, la jurisprudencia del Tribunal europeo de los derechos humanos. ${ }^{46}$

El punto de partida teórico es la afirmación según la cual del reconocimiento de parte del Estado, de un derecho fundamental, derivan, conjuntamente, obligaciones negativas y obligaciones positivas a cargo del mismo Estado. Las primeras son, esencialmente, deberes de abstención de conductas directamente lesivas del derecho; estos deberes vinculan a los agentes estatales, y corresponden al contenido 'clásico' liberal de los derechos fundamentales, que nacen históricamente para tutelar al ciudadano contra los abusos de los poderes públicos. Las segundas corresponden, en cambio, a la pretensión de los ciudadanos a recibir tutela de parte del Estado contra agresiones a sus derechos provenientes de terceros, e implican, entonces, un deber de actuar a cargo del Estado: es decir, de tomar todas las medidas exigibles en grado de prevenir similares agresiones.

La jurisprudencia del Tribunal de Estrasburgo en relación a las obligaciones positivas es, hoy, vastísima ${ }^{47}$, pero sus orígenes pueden ser trazados cuanto menos al paradigmático caso de 1985 X e Y c. Países Bajos, en el cual el Tribunal -en relación al derecho a la vida privada y familiar consagrada en el art. $8 \mathrm{CEDH}$ - afirmó textualmente: "las obligaciones positivas a cargo del Estado son inherentes al derecho al respeto efectivo de la vida privada sancionado en el art. 8; y estas obligaciones pueden implicar la adopción de medidas incluso en la esfera de las relaciones recíprocas entre los individuos". "Tales obligaciones

impunidad de las "más severas violaciones a los derechos humanos, que significan un grave menosprecio de la dignidad del ser humano y repugnan a la conciencia de la humanidad": Castillo Páez, cit. nota n²3, $\$ 7$; Barrios Altos, cit. nota ${ }^{\circ} 24, \S 11$.

${ }^{46}$ Sobre tal jurisprudencia, cfr. en la doctrina italiana BESTAGNO, Francesco, Diritti umani e impunità. Obblighi positivi degli Stati in materia penale, Milano: Vita e Pensiero, 2003; NICOSIA, Emanuele, Convenzione europea dei diritti dell'uomo e ordinamiento penale, Torino: Giappichelli, 2006, pp. 255 y ss.; CHENAL, Roberto, "Obblighi di criminalizzazione tra sistema penale italiano e Corte europea dei diritti dell'uomo", La legislazione penale, vol. no 26 (2006), pp. 171-190, pp. 181 y ss.; ESPOSITO, Andreana, Il diritto penale flessible: quando i diritti umani incontrano i sistemi penali, Torino: Giappichelli, 2008 , p. 226 ss.; VIGANÒ, Francesco, "Diritto penale sostanziale e Convenzione europea dei diritti dell'uomo", Rivista italiana di diritto e procedura penale (2007), pp. 42-99, pp. 60 y ss.; EL MISMO, "Il diritto penale sostanziale davanti ai giudici della CEDU”, Giurisprudenza di merito, suppl. al vol. XL, (2008), pp. 81-112, pp. 84 y ss.

Vid. sobre el punto, el profundo análisis de MOWBRAY, Alastair, The Development of Positive Obligations under the European Convenzion on Human Rights by the European Court of Human Rights, Portland: Hart, 2004.

${ }^{48}$ Tribunal EDH, X e Y c. Países Bajos (ric. n. 8978/80), sent. del 26 de marzo de 1985, § 23. Antes, la Corte había incluso afirmado que el derecho a la vida privada "does not merely compel the State to abstain from such interference: in addition to this primarily negative undertaking, there may be positive obligations inherent in an effective "respect" for family life": Tribunal EDH, Marcks c. Bélgica, sent. del 13 de junio de $1979, \S 31$. 
VIGANÒ, Francesco. "La arbitrariedad del no punir. Sobre las obligaciones de tutela penal de los derechos fundamentales".

comprenden no solo el deber de adoptar, en el caso concreto, todas las medidas razonables para prevenir violaciones a derechos fundamentales (y en particular a la vida) en las relaciones interpersonales, ${ }^{49}$ pero incluso el más general deber de predisponer un apropiado "legal framework" para disuadir eficazmente a los ciudadanos de cometer violaciones en perjuicio de terceros: ${ }^{50}$ un marco legal, entonces, que debe comprender necesariamente, en cuanto a las violaciones más graves a los más importantes entre los derechos reconocidos por el Convenio, la previsión de sanciones penales.

El primer caso en que el Tribunal reconoció una violación a las obligaciones positivas de tutela por un Estado en relación a la inexistencia en el ordenamiento interno de una norma incriminadora fue el propio $X$ e $Y$ c. Países Bajos. Aquí se apreciaba una laguna de punibilidad en el sistema de los delitos contra la libertad sexual previstos en el código penal holandés; en consecuencia de esta laguna, un abuso sexual cometido en contra de una joven afectada de una incapacidad psíquica resultaba no punible. La posibilidad de una tutela de carácter civilístico en favor de la joven fue, en esa ocasión, juzgada insuficiente por el Tribunal para garantizar la tutela de un derecho tan relevante como aquel de la libertad sexual, que pertenece al núcleo esencial de las posiciones subjetivas tuteladas por el art. 8 $\mathrm{CEDH}$, contra las posibles agresiones por parte de terceros: "éste es un caso", afirmó el Tribunal:

“en el cual están en juego valores fundamentales y aspectos esenciales de la vida privada. Aquí es indispensable poner en acción medidas capaces de asegurar una disuasión efectiva, que puede ser obtenida sólo a través de normas de carácter penal. Tanto es así que, normalmente, es precisamente a través de normas penales que la materia es regulada". 51

El precedente $X$ e Y c. Países Bajos quedó aislado durante más de diez años, hasta cuando el Tribunal -decidiendo sobre un recurso contra el Reino Unido originado por la absolución, en sede penal, de un padrastro que había golpeado repetidamente a su hijastro con un bastón jardinero con la intención de castigarlo, y que se había beneficiado, en sede procesal, de la common law defence de reasonable chastisment- estableció la

${ }^{49}$ Cfr. Osman c. Reino Unido (ric. n. 23452/94), sent. del 28 de octubre de 1998, § 115 y sucesivamente, ex plurimis, Paul e Audrey Edwards c. Reino Unido (ric. n. 46477), sent. del 14 de marzo de 2002, § 56; Mastromatteo c. Italia (ric. n. 37703/97), sent. del 24 de octubre de 2002, § 67; Branko Tomasic e a. c. Croacia (ric. n. 46598/06), sent. del 15 de enero de 2009, § 50, asimismo, Maiorano e a. c. Italia (ric. n. 28634), sent. del 15 de diciembre de 2009, § 104. Tal obligación subsiste incluso en relación a las conductas no intencionales, pero igualmente peligrosas para la vida (en relación al art. 2) o a la salud humana (art. 3): cfr. en particular L.C.B. c. Reino Unido (ric. n. 23413/94), sent. del 9 de junio de 1998, § 36, en materia de daños presuntamente sufridos por los recurrentes a consecuencia de la exposición del padre -militar del ejército británico- a las radiaciones nucleares; asimismo, en materia del art. 8, en relación a la posible responsabilidad del Estado por no haber adecuadamente tutelado la población circundante de la emisión de sustancias nocivas de instalaciones industriales (López Ostra c. España, ric. n. 16798/90, sent. del 9 de diciembre de 1994; Guerra e a. c. Italia, ric. n. 14967/89, sent. del 19 de febrero de 1998).

${ }^{50}$ Cfr. por ejemplo, en relación al derecho a la vida, Tribunal EDH, Kilic c. Turquía (ric. n. 22492/93), sent. del 28 de marzo de 2000, § 62, y, recientemente, Giuliani c. Italia (ric. n. 23458/02), sent. del 25 de agosto de $2009, \S 205$.

${ }^{51}$ Tribunal EDH, X e Y c. Países Bajos, cit. nota n 48, § 27. 


\section{Polít. crim. Vol. 9, № 18 (Diciembre 2014), Art. 5, pp. 428-476. [http://www.politicacriminal.cl/Vol_09/n_18/Vol9N18A5.pdf]}

responsabilidad del Estado por la ausencia de punición de la violación al derecho establecido en el art. $3 \mathrm{CEDH}$ (derecho a no sufrir tratamientos inhumanos y degradantes). ${ }^{52}$

Desde aquel momento similares pronunciamientos se multiplicaron, en relación a los derechos consagrados en los artículos 3 y $8,{ }^{53}$ así como en relación al derecho a la vida (art. 2) ${ }^{54}$ y al derecho a no ser sometido a esclavitud, servidumbre o trabajo forzado (art. 4). ${ }^{55} \mathrm{De}$ hecho, en un caso concerniente precisamente a esta última disposición convencional, el Tribunal reconoció la responsabilidad del Estado francés a pesar de la presencia, en aquel ordenamiento, de dos normas penales que sancionaban, aunque con penas poco más que simbólicas, la explotación de trabajadores, así como la sumisión del sujeto pasivo a condiciones de trabajo o de alojamiento incompatibles con la dignidad humana. ${ }^{56}$ Estas normas fueron, sin embargo, juzgadas como insuficientes para asegurar una "tutela concreta y efectiva" al derecho fundamental en juego, ${ }^{57}$ que según el Tribunal puede ser satisfecha únicamente con una incriminación directa a sancionar específicamente las violaciones a los derechos reconocidos en el Convenio. ${ }^{58}$

${ }^{52}$ Tribunal EDH, A. c. Reino Unido (ric. n. 100/1997/664/1096), sent. del 23 de septiembre de $1998, \S 24$.
${ }^{53}$ Cfr. Tribunal EDH, M.C. c. Bulgaria (ric. n. 39272/98), sent. del 4 de diciembre de 2003 , $\$ 153$, en relación
a la obligación de los Estados miembros de sancionar penalmente la violencia sexual (considerada como
conducta que infringe, conjuntamente, los derechos a que se refieren los artículos 3 y 8 del CEDH)
independientemente de la prueba de una resistencia activa de parte de la víctima.
${ }^{54}$ Cfr. Kilic c. Turquía, cit. nota ${ }^{\circ}$ 50, $\$$ 62, como también Mahmut Kaya c. Turquía (ric. n. 22535/93), sent. del 28 de marzo de 2000, $\S 85$, donde se solicita expresamente que el aparato sancionatorio del Estado, para tutelar la vida humana, sea capaz de conducir a la «punición» de los responsables; idéntica formulación en Paul e Audrey Edwards c. Reino Unido (ric. n. 46477), sent. del 14 de marzo de 2002, § 71. Cfr. también Nachova c. Bulgaria (ric. n. 43577/98 y 43579/98), sent. 6 de julio 2005, § 160, en el sentido de la necesidad de la previsión -y de la efectiva imposición en el caso concreto, como se argumentará en breve en el texto: cfr. infra, § 3.3- de una sanción penal contra los agentes públicos responsables de una violación del derecho a la vida cometida durante la ejecución de tareas de law enforcement. Cfr., también, por último, Maiorano e a. c. Italia (ric. n. 28634), sent. del 15 de diciembre de 2009, $\$ 104$, donde se reclama el "devoir primordial d'assurer le droit à la vie en mettant en place une législation pénale concrète dissuadant de commettre des atteintes contre la personne et s'appuyant sur un mécanisme d'application conçu pour en prévenir, réprimer et sanctionner les violations".

${ }^{55}$ Tribunal EDH, Siliadin c. Francia (ric. n. 73316/01), sent. 4 de diciembre 2005, § 112: "la Cour estime que, conformément aux normes et aux tendances contemporaines en la matière, il y a lieu de considérer que les obligations positives qui pèsent sur les Etats membres en vertu de l'article 4 de la Convention commandent la criminalisation et la répression effective de tout acte tendant à maintenir une personne dans ce genre de situations".

${ }^{56}$ Tribunal EDH, Siliadin, cit. nota $\mathrm{n}^{\circ} 55, \S 46$. Ambos delitos fueron, en efecto, imputados y aplicados en el caso en especie al empleador de la recurrente (una ciudadana togolesa empleada como doméstica de connacionales que la habían sometido a turnos de trabajo de quince horas al día sin ningún reposo a la semana y, sustancialmente, sin retribución); los imputados habían sido, incluso, absueltos por la Corte de Apelaciones, por ausencia de pruebas del requisito (común a los dos tipos penales) de la condición de vulnerabilidad de la víctima. Sobre el recurso, presentado únicamente por la parte civil, la Casación anuló la sentencia de absolución, pero limitadamente a sus efectos civiles, de modo que a la víctima se le reconoció únicamente un resarcimiento de naturaleza pecuniaria.

${ }^{57}$ Tribunal EDH, Siliadin, cit. nota $\mathrm{n}^{\circ} 55, \S 148$.

${ }^{58}$ Esto se deduce a contrario sensu del $\S 142$ de la referida sentencia, en donde el Tribunal reprueba en particular a la norma incriminadora francesa el no estar específicamente orientada a tutelar los derechos garantizados en el Convenio. La sentencia concede igualmente un amplio espacio a un reporte de la misma 
El Tribunal, por cierto, nunca ha afirmado una obligación general de sancionar penalmente todas las violaciones de todos los derechos convencionales. Más bien, actúa valorando caso por caso, cuando se le presenta la ocasión, si el derecho convencional en el caso especifico invocado exige, en la óptica del Convenio, una tutela incluso de carácter penal de parte del Estado. ${ }^{59}$

Aún en relación al derecho a la vida y al derecho a no ser sometido a tortura o tratamientos inhumanos y degradantes, el Tribunal ha establecido que la obligación de disponer una tutela penal se extiende únicamente a las violaciones intencionales del derecho en cuestión, y no a la hipótesis de mera negligencia, donde remedios de otra naturaleza (en la especie civilísticos-resarcitorios o disciplinarios) pueden ser considerados idóneos para satisfacer las obligaciones de tutela efectiva derivadas del Convenio. ${ }^{60}$ De modo que puede afirmarse que las obligaciones de tutela penal individualizadas por el Tribunal se refieren únicamente a las violaciones más graves de los más fundamentales entre los derechos reconocidos en el Convenio -según, claro está, la soberana apreciación del Tribunal, que gradualmente se está consolidando en una jurisprudencia case by case, carente de toda explícita base textual.

La ratio de tal jurisprudencia es, sin embargo, inequívoca. Como hemos visto, ya en el leading case $X$ e Y c. Países Bajos el Tribunal recalcó la necesidad de conferir una dimensión de efectividad a los derechos convencionales, y la conectada exigencia de asegurar una (efectiva) disuasión hacia los ciudadanos, para desincentivarlos de la comisión de violaciones contra otros individuos. Este punto de vista ha sido constantemente reiterado en la jurisprudencia del Tribunal, incluso en la reciente sentencia de la Gran Cámara Gäfgen c. Alemania -sobre la cual volveremos dentro de poco-, en la cual textualmente se afirma que:

Assemblée Nationale francesa que, en el 2001, había denunciado la manifiesta insuficiencia de la tutela penal regulada en el ordenamiento penal francés contra las modernas formas de esclavitud, como también en relación a lo exiguo de las penas privativas de libertad (no superiores a dos años de reclusión) conminadas en las dos normas penales en referencia ( $\$ 48$ y 134).

${ }^{59}$ El Tribunal suele acompañar el reconocimiento de la obligación de penalización de la violación de un determinado derecho convencional con la afirmación de que tal derecho constituye "uno de los valores fundamentales de la sociedad democrática que forman el Consejo de Europa” (así, por ejemplo, Tribunal EDH, Siliadin, cit. nota $\mathrm{n}^{\circ} 55, \S \S 82$ y 112).

${ }^{60}$ Así, Tribunal EDH, Calvelli e Ciglio c. Italia (ric. n. 32967/96), sent. del 17 de enero de 2002 (Gran Cámara), § 90; Vo c. Francia (ric. n. 53924/00), sent. 8 de julio de 2004, 90 ("the Court has stated on a number of occasions that an effective judicial system, as required by Article 2, may, and under certain circumstances must, include recourse to the criminal law. However, if the infringement of the right to life or to physical integrity is not caused intentionally, the positive obligation imposed by Article 2 to set up an effective judicial system does not necessarily require the provision of a criminal-law remedy in every case. In the specific sphere of medical negligence, the obligation may for instance also be satisfied if the legal system affords victims a remedy in the civil courts, either alone or in conjunction with a remedy in the criminal courts, enabling any liability of the doctors concerned to be established and any appropriate civil redress, such as an order for damages and for the publication of the decision, to be obtained. Disciplinary measures may also be envisaged"). La afirmación es, textualmente, reiterada en el fallo G.N. e a. c. Italia (ric. n. 43134/05), sent. del 1 de diciembre de 2009, § 82 . 


\section{Polít. crim. Vol. 9, № 18 (Diciembre 2014), Art. 5, pp. 428-476. [http://www.politicacriminal.cl/Vol_09/n_18/Vol9N18A5.pdf]}

"en el caso de tortura o tratamientos inhumanos o degradantes la violación del art. 3 no puede ser remediada únicamente a través del resarcimiento pecuniario a la víctima. $\mathrm{Si}$, de hecho, la autoridad pudiese limitar su reacción frente a conductas de este tipo por parte de los mismos funcionarios estatales al mero pago de un resarcimiento pecuniario sin promover la acción penal y punir a los responsables, sería posible, en ciertos casos, para los agentes del Estado abusar de los derechos de los individuos sometidos a su control confiando en su virtual impunidad. La prohibición general de la tortura y de los tratamientos inhumanos o degradantes, aun cuando prescrita en la ley, devendría así inefectiva en la praxis, no obstante su importancia fundamental". ${ }^{61}$

Sin embargo, ni en $X$ e $Y$ c. Países Bajos ni después la Corte ha articulado una argumentación detallada para justificar el reconocimiento de obligaciones de tutela penal, por lo menos de algunos derechos, en relación a las agresiones más graves. A lo sumo, el Tribunal se ha limitado a invocar en estas hipótesis -junto a la norma que prevé el derecho respecto del cual viene reconocida la violación- la norma general consagrada en el art. 1 $\mathrm{CEDH}$, que impone a los Estados miembros tutelar los derechos convencionales al interno de la respectiva jurisdicción ${ }^{62}$, deduciendo implícitamente de tal fórmula el entero conjunto de obligaciones tendientes a garantizar efectividad a la tutela de los derechos convencionales, incluso en las relaciones entre los particulares. ${ }^{63}$

Por otra parte es claro -aunque menos explícito de lo que se aprecia en la jurisprudencia interamericana- el nexo entre la afirmación de obligaciones de criminalización y la exigencia de tutela de la víctima de la violación. El sistema de tutela regulado en el Convenio europeo se funda, exactamente como en el interamericano, en el principio según el cual el Estado miembro está directamente obligado a ofrecer a la víctima de una violación un recurso efectivo (art. 13), capaz de permitir un remedio adecuado a la violación; únicamente en el caso en el cual el Estado no ha cumplido con este deber, y habiendo la víctima agotado todas las vías de recursos disponibles al interno del ordenamiento (art. 35), el Tribunal se reserva el derecho de intervenir para verificar la violación, y asegurar la reparación del derecho violado y/o una justa satisfacción a la víctima (art. 41). El recurso ante el Tribunal es, en cambio, inadmisible si el Estado ya ha proporcionado una adecuada tutela en el ordenamiento interno a la víctima de la violación, reconociendo "explícita y sustancialmente" la propia violación y proveyendo a su reparación. ${ }^{64}$ Ahora, en el caso en que el Tribunal reconozca una obligación de tutela penal de un determinado derecho, él afirma constantemente que el recurso al Tribunal debe considerarse admisible cada vez que el ordenamiento no ha logrado asegurar, dentro de un plazo razonable, el juicio y la condena en sede penal de los responsables de las

\footnotetext{
${ }^{61}$ Tribunal EDH, Gäfgen c. Germania (ric. n. 22978/05), Gran Cámara, sent. del 1 de junio de 2010, § 119, y los precedentes citados ahí.

${ }^{62}$ Así, por ejemplo, Tribunal EDH, Ergi c. Turquía (ric. n. 23818/94), sent. del 28 de julio de 1998, § 79.

${ }^{63}$ Cfr., sobre el punto, de nuevo MOWBRAY, The Positive Obligations, cit. nota n ${ }^{\circ} 47,221$.

${ }^{64}$ Jurisprudencia constante: cfr., ex multis, Tribunal EDH, Amuur c. Francia (ric. n. 19776/92), sent. del 25 de junio de 1996, § 36. En la hipótesis, en cambio, en que el Estado haya asegurado una reparación adecuada, aquél que ha sufrido la violación perdería, en el lenguaje del Tribunal, el propio estatus de "víctima", cuya posesión es condición para poder ejercitar el recurso al sentido del art. $34 \mathrm{CEDH}$ : cfr. ampliamente, sobre el punto, Tribunal EDH, Gäfgen, cit. nota $\mathrm{n}^{\circ} 61, \S 109$ ss., y otros precedentes ahí citados.
} 
VIGANÒ, Francesco. "La arbitrariedad del no punir. Sobre las obligaciones de tutela penal de los derechos fundamentales".

violaciones; y esto incluso en la hipótesis en que la víctima haya obtenido o hubiera podido obtener una reparación de carácter resarcitorio, que es -como habíamos visto- considerada en estos casos insuficiente para asegurarle una adecuada reparación ${ }^{65} \mathrm{y}$, por lo mismo, inidónea para integrar aquel "recurso efectivo", al cual ella habría tenido derecho en virtud del art. $13 .^{66}$

Todo esto revela, por lo tanto, que también para el Tribunal europeo la tutela penal se revela en algunos casos como la única reparación adecuada para la víctima de la violación, que el Estado debe necesariamente asegurarle para satisfacer sus propias obligaciones convencionales.

\subsection{Las implicaciones prácticas}

Como se ha dicho examinando la jurisprudencia paralela de San José, tampoco para el Tribunal europeo las obligaciones de tutela penal a cargo del Estado se agotan por la mera presencia de una norma incriminadora de la violación al derecho convencional. Esas obligaciones exigen, además, que se llegue a la efectiva punición, en el caso concreto, del responsable de la violación. ${ }^{67}$

De ello se deduce, primero que todo, la prohibición al Estado de prever en abstracto causas de justificación para los autores de la violación, así como causas que, de todos modos, impliquen su no punibilidad, sustrayendo las conductas al radio de operatividad de una correspondiente norma incriminadora -fuera de las hipótesis, naturalmente, en las cuales la lesión del derecho convencional deba ser considerada legítima también bajo la óptica del Convenio. Tal prohibición se infiere, claramente, en el citado caso A. c. Reino Unido, donde el Estado inglés fue censurado precisamente por la presencia, en el ordenamiento interno, de una causa de justificación -la reasonable chastisment defence- capaz de sustraer de la punición conductas injustificadamente lesivas (desde la perspectiva convencional) del art. $3 \mathrm{CEDH}^{68}$, pues sus vagos confines quedaban confiados a la libre apreciación del jurado. En dos casos sucesivos, concernientes a supuestos de uso de la fuerza letal por parte de la policía griega y búlgara en ausencia de las taxativas condiciones de licitud previstas en el art. $2 \S 2 \mathrm{CEDH}$, el Tribunal reprochó a los Estados requeridos precisamente la presencia, en los respectivos ordenamientos jurídicos, de causas de justificación del uso de las armas con confines demasiado amplios y genéricos respecto a

\footnotetext{
${ }^{65}$ Cfr. Tribunal EDH, Gäfgen, cit. nota ${ }^{\circ} 61, \S 119$.

${ }^{66}$ Vid. v.gr. en este sentido, Tribunal EDH, Giuliani c. Italia (ric. n. 23458/02), sent. del 6 de febrero de 2007; en el mismo sentido, anteriormente, Scavuzzo-Hager e a. c. Suiza (ric. n. 41773/98), sent. del 7 de febrero de 2006, § 79 .

${ }^{67}$ Cfr. sobre el punto, NICOSIA, Convenzione europea, cit. nota ${ }^{\circ} 46$, p. 262.

${ }^{68}$ Es este respecto, ocurre en efecto considerar que el derecho a no ser sometido a tortura y/o tratamientos inhumanos o degradantes es considerado por la Corte como absoluto, y no susceptible de alguna ponderación con intereses contrapuestos; de lo que desciende, en la óptica convencional, la inadmisibilidad de alguna causa de justificación, que pretenda descriminalizar conductas consideradas lesivas de tal derecho. Otra cuestión, naturalmente, es aquella de valorar sí, y en qué medida, el Tribunal de hecho realiza (subrepticiamente) ponderaciones con otros intereses al fin de establecer si una determinada conducta alcanza o no el umbral del tratamiento "inhumano" o "degradante".
} 


\section{Polít. crim. Vol. 9, № 18 (Diciembre 2014), Art. 5, pp. 428-476. [http://www.politicacriminal.cl/Vol_09/n_18/Vol9N18A5.pdf]}

los estándares de tutela del derecho a la vida impuestos en el Convenio: ${ }^{69}$ afirmando así, implícitamente, una exigencia de precisión de la norma que excluye la antijuridicidad, cuyo confín debe ser delimitado en modo claro en la ley, en nombre de una tutela eficaz del derecho a la vida de las potenciales víctimas del uso de la fuerza por la policía.

Asimismo, el Tribunal europeo, como la Corte interamericana, insiste en la obligación a cargo del Estado de investigar las supuestas violaciones de los derechos respecto a los cuales subsiste una obligación de tutela penal. ${ }^{70}$ La jurisprudencia de Estrasburgo habla aquí de una autónoma categoría de obligaciones procedimentales que se desprenden en particular de los arts. 2 y 3 del Convenio, resumibles precisamente en el deber a cargo del Estado de realizar, en cada caso de violación de tales derechos, "una investigación acuciosa y efectiva, capaz de conducir a la identificación y la punición de los responsables", 71 según un estándar detalladamente articulado que comprende, entre otros, el carácter necesariamente ex officio del procedimiento, su transparencia y celeridad, la independencia de la autoridad encargada de la investigación respecto de aquella que se sospecha ha cometido la violación, así como la posibilidad de participación activa de la víctima en todo el procedimiento.

Al igual que como sucede con la Corte interamericana, el Tribunal de Estrasburgo no se esfuerza demasiado en buscar una fundamentación textual de tales obligaciones, genéricamente deducidas de lo dispuesto por el art. $1 \mathrm{CEDH}$ en relación a las disposiciones que prevén el derecho violado en el caso especifico (arts. 2 o 3), así como de la general exigencia de asegurar una tutela efectiva de los derechos fundamentales. ${ }^{72}$ Sin embargo, el sentido de esta jurisprudencia es evidente: no basta que el Estado prevea en el papel la pena para aquellas violaciones: la tarea del Estado es, también, asegurar el enforcement de tales incriminaciones, por medio de llevar a cabo una diligente actividad de investigación dirigida a identificar a los responsables de las violaciones, y la consecuente celebración de un proceso penal contra ellos mismos. ${ }^{73}$

\footnotetext{
${ }^{69}$ Tribunal EDH, Makaratzis c. Grecia (ric. n. 50385/99), sent. del 20 de diciembre de 2004 (Gran Camara), § 56-62; Tribunal EDH, Nachova, cit. § 99-102. Sobre el punto, cfr. más ampliamente VIGANÒ, "Il diritto penale sostanziale", cit. nota $\mathrm{n}^{\circ} 46$, p. 92.

${ }^{70}$ El leading case a este respecto lo constituye el caso McCann c. Reino Unido (ric. n. 18984), sent. del 27 de noviembre de 1995, $\S 161$, en tema de art. 2 CEDH. La idea de obligaciones, así llamadas, procedimentales, procedentes de los arts. 2 y 3 , ha sido retomada y desarrollada en una vastísima jurisprudencia, sobre cuyas características esenciales cfr. VIGANÒ, "Il diritto penale sostanziale", cit. nota n 46, p. 92.

${ }^{71}$ Para esta formulación, cfr. v. gr. Abdülsamet Yaman c. Turquía (ric. n. 32446/96), sent. del 2 de noviembre de 2004, §53.

${ }^{72}$ En McCann c. Reino Unido, cit. nota $n^{\circ} 70, \S 161$ el Tribunal se limita a subrayar, a propósito, que “a general legal prohibition of arbitrary killing by agents of the State would be ineffective, in practice, if there existed no procedure for reviewing the lawfulness of the use of lethal force by State authorities. The obligation to protect the right to life under this provision (art. 2), read in conjunction with the State's general duty under Article 1 of the Convention to 'secure to everyone within their jurisdiction the rights and freedoms defined in [the] Convention', requires by implication that there should be some form of effective official investigation when individuals have been killed as a result of the use of force by, inter alios, agents of the State".

${ }^{73}$ Observa de otra parte, perspicazmente, MOWBRAY, The Development cit. nota $\mathrm{n}^{\circ}$ 47, p. 222, que el reconocimiento de obligaciones procesales a cargo del Estado en materia de violaciones de los arts. 2 y 3 CEDH es también funcional a la exigencia práctica, surgida frente al exponencial aumento de contenciosos en
} 
De manera coherente, el Tribunal exige que, una vez establecida la culpabilidad del responsable de la violación, éste sea concretamente punido, y no pueda escapar a la pena por efecto de una causa de no punibilidad de índole sustancial o procesal, como la prescripción, la amnistía o, incluso, el indulto individual. Tal principio ha sido afirmado con claridad, en particular, en casos relativos al abuso de la fuerza por parte de agentes públicos: "cuando un agente estatal es acusado por delitos de tortura o malos tratos, es de esencial importancia respecto a la exigencia de proporcionar un "remedio efectivo" que el proceso penal y la pena no sean declarados prescritos, y que el responsable no pueda beneficiarse de medidas de amnistía o de indulto". ${ }^{74}$ En tales hipótesis, más bien, la constante jurisprudencia del Tribunal demanda que -en presencia de serios indicios de comisión de la violación por parte del agente público- éste sea suspendido del servicio, antes de que quede plenamente establecida la responsabilidad en sede procesal. $^{75}$

En suma: también para el Tribunal europeo, como para la Corte interamericana, el "remedio efectivo" que el Estado está obligado a asegurar a la víctima de graves violaciones a los más importantes de los derechos convencionales comporta: la individualización de los responsables, a través de investigaciones efectivas; su sometimiento a un proceso; y, al final, la efectiva punición, no conformándose el Tribunal con una mera afirmación de la responsabilidad por la violación cometida, cuando de ella no se siga la imposición en concreto de la pena.

los últimos años relativos a tales violaciones por parte de Turquía y Rusia, de evitar largas y costosas misiones in loco de parte del Tribunal para establecer los hechos de la causa. La imposición de una obligación a cargo de los Estados requeridos -por violaciones, al menos, de sus obligaciones procesales- permite de hecho la condena del Estado, cada vez que el Tribunal no disponga de informaciones suficientes para considerar probados los hechos alegados por el recurrente, pero precisamente este defecto de informaciones puede ser atribuido a la negligencia de la autoridades estatales en la conducción de las investigaciones, si no en los casos más extremos- directamente a su complicidad con los autores materiales.

74 Tribunal EDH, Abdülsamet Yaman, cit. nota $\mathrm{n}^{\circ} 74, \S 55$. En el mismo sentido cfr. la constante jurisprudencia sucesiva del Tribunal: cfr. v. gr. Okkali c. Turchia (ric. n. 52067/99), sent. del 17 octubre de 2007, § 76; Erdogan Yilmaz (ric. n. 19374/03), sent. del 14 octubre de 2008, § 56; Müdet Kömürcü c. Turchia, sent. del 21 julio de 2009, § 29. El principio ha sido aplicado también a un país de solida tradición jurídica y democrática como Bélgica - Turan Cakir c. Belgio (ric. n. 44256/06), sent. del 10 de marzo de 2009, § 69 -, que fue condenado en un caso en el cual una acción penal por crímenes reconducibles al ámbito del art. 3 CEDH había sido declarada prescrita ("la Cour rappelle qu'elle a déjà jugé que lorsqu'un agent de l'Etat est accusé d'actes contraires à l'article 3, la procédure ou la condamnation ne sauraient être rendues caduques par une prescription, et l'application de mesures telles que l'amnistie ou la grâce ne saurait être autorisée [...]. En particulier, la Cour considère que les autorités nationales ne doivent en aucun cas donner l'impression qu'elles sont disposées à laisser de tels traitements impunis". Cfr. también, recentísimamente, Paduret c. Moldavia (ric. n. 33134/03), sent. del 5 enero de 2010, $§ 72$ ss., donde el Tribunal censura al Estado por haber considerado prescritos los hechos de tortura cinco años después de su comisión, reiterando (§ 75) que ningún término de prescripción debe aplicarse a casos de tortura o en general de ill-treatments cometidos por los agentes del Estado.

${ }^{75}$ Tribunal EDH, Abdülsamet Yaman, cit. nota $n^{\circ} 71, \S 55$. En el mismo sentido, cfr. prácticamente todas las sentencias citadas en la nota precedente. 


\section{Polít. crim. Vol. 9, № 18 (Diciembre 2014), Art. 5, pp. 428-476. [http://www.politicacriminal.cl/Vol_09/n_18/Vol9N18A5.pdf]}

\subsection{La proporcionalidad de la pena concretamente impuesta respecto a la gravedad de la violación}

Respecto a la homóloga jurisprudencia de San José, sin embargo, el Tribunal europeo avanza un paso más, en la medida en que su control se extiende también al quantum de la respuesta sancionatoria.

De hecho se están multiplicando, en los últimos años, pronunciamientos en los cuales el Tribunal reconoce la responsabilidad del Estado, cuando la pena conminada en abstracto para conductas lesivas de los core rights reconocidos en el Convenio, ${ }^{76}$ o la pena en concreto impuesta al condenado, son consideradas por el Tribunal desproporcionadas por defecto respecto a la gravedad de la misma violación: ${ }^{77}$ lo que sucede, en particular, en las hipótesis en las cuales la pena tiene naturaleza exclusivamente pecuniaria, o bien es suspendida condicionalmente. ${ }^{78}$ Similares penas -las cuales, cuando el autor es un agente estatal, transmiten la impresión de una impropia tolerancia, o incluso de colusión por parte del Estado $^{79}$ - son consideradas por el Tribunal inidóneas para expresar la solemne reprobación del ordenamiento por la violación del derecho convencional, para asegurar una verdadera eficacia disuasiva en relación a los potenciales futuros autores (los cuales terminarán más bien por contar con una virtual impunidad), así como para asegurar un "remedio efectivo" a las víctimas de las violaciones.

Esta jurisprudencia ha recibido, recientemente, el respaldo de la Gran Cámara en un caso muy relevante y de gran sensibilidad política (Gäfgen c. Alemania), en el cual se determinó la responsabilidad del Estado alemán por la violación del art. $3 \mathrm{CEDH}$, después que la Cámara de primera instancia había, en cambio, excluido tal responsabilidad. Dos agentes de la policía alemana habían amenazado al arrestado, durante el interrogatorio, de someterlo a

\footnotetext{
${ }^{76}$ Cfr. en particular, en relación a las violaciones al art. $3 \mathrm{CEDH}$, Tribunal EDH, Paduret c. Moldavia, cit. $\mathrm{n}^{\circ}$ 74, § 77: "the Court notes with great concern the Government's assertion that in Moldova torture was considered an "average-level crime", to be distinguished from more serious forms of crime and thus warranting reduced sentences [...]. Such a position is absolutely incompatible with the obligations resulting from Article 3 of the Convention, given the extreme seriousness of the crime of torture. Together with the other shortcomings mentioned in paragraphs 72-76 above, this confirms the failure of the Moldovan authorities to fully denounce the practice of ill-treatment by the law-enforcement agencies and adds to the impression that the legislation adopted to prevent and punish acts of ill-treatment is not given full preventive effect. [...]. As such, the case gives the impression of not preventing any future similar violations, but of being an example of virtually total impunity for ill-treatment by the law-enforcement agencies".

77 Cfr. v. g. Okkali c. Turquía, cit., § 73-75, donde el Tribunal censura duramente las decisiones de los tribunales nacionales de reconocer una serie de circunstancias atenuantes a un imputado de actos contrarios al art. $3 \mathrm{CEDH}$, y de imponer sucesivamente una pena juzgada en concreto excesivamente suave, y como tal incapaz de generar efecto disuasivo para el futuro («as to the severity of the sentences pronounced, it can only be said that, in sentencing the police officers to the minimum penalties, the courts overlooked a number of factors - such as the particular nature of the offence and the gravity of the damage done - which they should have taken into account under Turkish law [...]. In view of the above, the Court considers that the impugned court decision suggests that the judges exercised their discretion more in order to minimise the consequences of an extremely serious unlawful act than to show that such acts could in no way be tolerated»).

${ }^{78}$ Tribunal EDH, Nikolova e Velikova (ric. n. 7888/03), sent. del 20 de diciembre 2007, § 63 y Ali and Ayse Duran c. Turquía (ric. n. 42942/02), sent. 8 de abril de 2008, § 66.

${ }^{79}$ Así Okkali c. Turchia, cit. nota ${ }^{\circ} 74, \S 65$.
} 
VIGANÒ, Francesco. "La arbitrariedad del no punir. Sobre las obligaciones de tutela penal de los derechos fundamentales".

tortura en el caso en que éste no revelara el lugar donde sus propios cómplices tenían secuestrado a un menor. Los agentes fueron procesados y condenados por coacciones a una pena pecuniaria suspendida, habiendo el tribunal considerado a su favor la excepcionalidad de las circunstancias del hecho -en particular la razonable creencia de los imputados que la vida del menor estaba en inminente peligro de muerte-; tales circunstancias no justificaban ni excusaban totalmente sus conductas, pero ciertamente disminuían de manera considerable su reprochabilidad, también en relación a la escasa ofensividad de la conducta (que, conviene recordarlo, no había implicado el uso de violencia física alguna). Investida por el recurso de la persona ofendida, la Cámara de primera instancia había negado su calidad de "víctima" conforme al art. 34 en relación a la violación alegada del art. 3 CEDH, ya que el Estado alemán había expresamente reconocido tal violación mediante la condena penal de los responsables. Acogiendo la apelación del recurrente, la Gran Cámara revocó tal decisión, considerando insuficiente la respuesta sancionadora impuesta por el Estado alemán, con una motivación que vale la pena replicar extensamente acá:

"El Tribunal reitera en este contexto que no es tarea propia valorar el grado de las responsabilidades individuales [...] ni determinar la pena apropiada para un reo, tratándose de cuestiones reservadas a la competencia exclusiva de los tribunales penales nacionales. Sin embargo, en base al art. 19 del Convenio y en razón del principio que el Convenio tiene como fin garantizar derechos para que no sean sólo teóricos e ilusiorios, sino que prácticos y efectivos, el Tribunal debe asegurar que la obligación a cargo del Estado de tutelar los derechos de aquellos que se encuentran en su propia jurisdicción sea adecuadamente cumplida [...] De ello se deduce que el Tribunal, aún reconociendo el rol de los tribunales nacionales en la elección de las sanciones apropiadas por los malos tratos cometidos por los agentes del Estado, debe mantener sus funciones de supervisión e intervenir en caso de manifiesta desproporción entre la gravedad de la conducta y la pena impuesta. En caso contrario, el deber del Estado de conducir una investigación efectiva perdería mucho de su significado [...]. El Tribunal es plenamente consciente que el Landgericht de Frankfurt am Main, al determinar la pena para los dos imputados, ha tenido en consideración una cantidad de circunstancias atenuantes [...], y reconoce que el caso en cuestión no es comparable con otros casos que conciernen a actos arbitrarios y graves de brutalidad ejecutados por agentes del Estado, que después toman medidas para ocultar la prueba, y respecto de los cuales la Corte ya ha afirmado que la imposición de pena privativa de libertad no suspendida constituye una pena más apropiada [...]. Sin embargo, la condena al pago respectivamente de 60 y 90 cuotas diarias de 60 y 120 euros, acompañada por lo demás de la suspensión condicional de tal pena, no puede ser considerada como una respuesta adecuada a una violación del art. 3 , ni siquiera en el contexto general de la práctica sancionatoria del Estado requerido. Una pena similar, que es manifiestamente desproporcionada respecto a uno de los derechos fundamentales (core rights) de la Convención, no posee el necesario efecto disuasivo para prevenir futuras violaciones de la prohibición de malos tratamientos en futuras situaciones críticas". 80

\footnotetext{
${ }^{80}$ Tribunal EDH, Gäfgen, cit. nota n ${ }^{\circ} 61, \S 123-124$.
} 
Polít. crim. Vol. 9, Nº 18 (Diciembre 2014), Art. 5, pp. 428-476.

[http://www.politicacriminal.cl/Vol_09/n_18/Vol9N18A5.pdf]

Una vez más el acento se pone aquí sobre la exigencia de la efectividad de la tutela de los derechos fundamentales, de los cuales se deducen, incluso, exigencias de proporcionalidad en concreto de la pena respecto a la gravedad de la violación, al doble objetivo de asegurar un efecto disuasivo contra futuras violaciones, y de proporcionar un adecuado alivio a la víctima por la violación sufrida -objetivo, este último, implícito en la lógica que gobierna la admisibilidad de los recursos individuales presentados ante la Corte, y que presupone la falta de reparación de las violaciones de parte del Estado.

\subsection{Efectos internos}

¿Cuáles son los efectos de la jurisprudencia hasta aquí esbozados en los ordenamientos penales internos de cada Estado parte del CEDH?

Vale la pena, primero que todo, subrayar que a diferencia de lo que ha acontecido en el continente americano, el Tribunal europeo no ha llegado nunca a pretender que los jueces penales de los Estados desapliquen la norma de la cual desciende la no punibilidad de los responsables de las violaciones de los derechos convencionales, ni mucho menos que se reabran investigaciones o procesos ya archivados (o declarados extintos por efectos de la prescripción o de una amnistía) a cargo de ellos. En casos similares, la reacción del Tribunal ha sido, hasta ahora, simplemente la de afirmar la responsabilidad del Estado por la violación de las propias obligaciones convencionales, con la consecuente condena a una indemnización de carácter pecuniario en favor del recurrente. Tampoco los jueces de Estrasburgo se han atrevido, hasta ahora, a condenar al Estado a modificar la legislación (penal) vigente con el objetivo de eliminar los obstáculos a la efectiva punición de (futuros) responsables de otras violaciones.

En términos generales, el impacto de la jurisprudencia de Estrasburgo sobre los sistemas penales internos europeos -no sólo, por lo tanto, en relación a la temática, aquí en discusión, de las obligaciones de tutela penal- ha sido, por el momento, incomparablemente menos relevante de cuanto ha acaecido en el continente americano.

Esto no quiere decir, sin embargo, que no sean imaginables desarrollos importantes en el futuro próximo.

Limitando aquí el discurso al ordenamiento italiano, vale la pena retomar la consideración desarrollada en la introducción- según la cual las obligaciones de tutela penal de fuente supranacional, incluso aquellas que se desprenden de la adhesión de Italia al CEDH, se traducen en obligaciones constitucionales de tutela penal, en razón del mecanismo establecido por el art. 117 inc. 1 Const., según la lectura realizada en las dos sentencias n. 348 y 349/2007 de la Corte constitucional italiana.

La cuestión que inmediatamente se pone en evidencia es, por lo tanto, aquella de establecer con qué límites la Corte constitucional puede sancionar las violaciones de parte del legislador italiano de aquellas mismas obligaciones. 
Al estado actual de la jurisprudencia constitucional, los límites del control aparecen, como se ha dicho, limitados a la normas penales, así llamadas, favorables, según los principios recapitulados en la sentencia n. 394/2006: no hay ningún remedio contra la omisión, tout court, de una norma incriminadora, ni contra la previsión de una sanción penal inadecuada respecto a los estándares impuestos en sede europea; sólo existe la posibilidad de declarar constitucionalmente ilegítima una norma que, en contraposición con las obligaciones supranacionales, sustraiga del ámbito aplicativo de otra norma incriminadora existente (y contemporáneamente vigente) una subclase de hechos, susceptibles de ser reconducidos a la norma general una vez declarada la ilegitimidad de aquella especial. Este mecanismo fue utilizado por primera vez por la Corte en la reciente sentencia n. 28/2010 en relación a las obligaciones de criminalización que surgen de la directivas comunitarias en materia de desechos, pero bien podría ser aplicada incluso respecto a las obligaciones de tutela penal que se desprenden del CEDH.

Retomando un ejemplo ya formulado en otra ocasión, ${ }^{81}$ imaginémonos que el legislador italiano se decida finalmente a introducir en el ordenamiento italiano una norma incriminadora de la tortura, previendo, al mismo tiempo, que el hecho no sea punible cuando es realizado "en cumplimiento de una obligación legal"; e imaginémonos que el juez, en el contexto de un procedimiento penal iniciado contra un funcionario público que invoca tal eximente, reenvíe los antecedentes del proceso a la Corte constitucional asumiendo una antinomia entre esta causa de justificación y el art. 117 inc. 1 Const. en relación al art. $3 \mathrm{CEDH}$, así como interpretado en la constante jurisprudencia de la Corte (que considera, como se ha visto, inadmisible cualquier causa de justificación que pueda excluir la pena contra los autores de los actos de tortura). Nada se opondría, aquí, a un pronunciamiento de la Corte que elimine esta causa de justificación, encuadrable como "norma penal favorable" según el esquema diseñado en la sentencia n. 394/2006, tratándose de una norma contemporáneamente vigente respecto a aquella que incrimina los hechos de tortura, y que extrae un subconjunto de hechos respecto al conjunto cubierto por la lex generalis, con la consecuente posibilidad de re-expansión de esta última en el caso en el cual venga declarada ilegítima la norma favorable. Se mantendría a salvo, por supuesto, la no punibilidad del autor en razón del principio de irretroactividad prescrito en el art. 25 inc. 2 Const.; pero la sentencia de la Corte tendría efectos para el futuro, eliminando del ordenamiento una causa de justificación que ilícitamente podría asegurar la impunidad de los autores de gravísimas violaciones a derechos fundamentales.

Se debería proceder de forma análoga -y retomo nuevamente un ejemplo ya desarrollado en otro texto ${ }^{82}$ - en relación a varias normas italianas vigentes que autorizan el uso de armas por parte de la fuerza pública en hipótesis más extensivas que aquellas previstas en el art. 2 CEDH. Tales normas, introduciendo indebidas excepciones a las obligaciones de tutela (penal) de la vida humana, podrían ser sin dificultad declaradas ilegítimas por la Corte constitucional. $^{83}$

\footnotetext{
${ }^{81}$ VIGANÒ, "Il diritto penale sostanziale", cit. nota n ${ }^{\circ} 46$, p. 84.

${ }^{82}$ VIGANOे, "Il diritto penale sostanziale", cit. nota ${ }^{\circ} 46$, pp. 66 s. y 85.

${ }^{83}$ Observa perspicazmente BARTOLI, Roberto, "Incriminazione e giustificazione: una diversa legalità?", Rivista italiana di diritto e procedura penale, (2010), pp. 597-632, p. 598, que «dopo un lungo periodo in cui
} 
Polít. crim. Vol. 9, № 18 (Diciembre 2014), Art. 5, pp. 428-476.

[http://www.politicacriminal.cl/Vol_09/n_18/Vol9N18A5.pdf]

\section{Algunas reflexiones críticas}

Los escenarios mencionados reabren las inquietantes interrogantes esbozadas al inicio de este trabajo. ¿Es legítimo que la jurisprudencia 'creativa' de dos Cortes internacionales, a las que los Estados parte les han conferido la misión de asegurar el respeto de textos convencionales que nada dicen a propósito de la tutela penal de los derechos fundamentales, puedan producir un cambio así radical de la tradicional relación entre el derecho penal y los derechos humanos, entendiendo estos últimos no sólo como límites a la intervención punitiva estatal, sino también como razones que exigen su activación (en abstracto y en concreto)? ¿Y es legítimo -ésta es la pregunta que quizás más inquieta al penalista- que aquellos jueces internacionales, mayoritariamente de formación no penal, pretendan imponer a los ordenamientos nacionales una concepción marcadamente reparatoria de la pena y del mismo proceso penal respecto a los intereses de la víctima, en diametral contraste con las modernas concepciones de las funciones de la pena?

\subsection{La problemática legitimación de las obligaciones "positivas" de tutela de los derechos fundamentales mediante el derecho penal}

Comenzando con la primera de las inquietudes, se ha visto como ambas Cortes, europea e interamericana, deducen la existencia de una obligación de tutela penal de algunos derechos fundamentales, del deber del Estado parte de asegurar el respeto de tales derechos al interno de sus ordenamientos $\mathrm{y}$, más en general, de la dimensión de efectividad que tales derechos deben poseer. En particular, el Tribunal de Estrasburgo encuadra las obligaciones de tutela penal entre la más vasta categoría de las obligaciones positivas de tutela, las cuales tienen como objeto no ya la abstención de conductas directamente lesivas del derecho individual por parte de los agentes del Estado, sino la adopción de medidas de tutela del derecho contra las agresiones provenientes de terceros. ${ }^{84}$

\footnotetext{
le scriminanti, rappresentando norme favorevoli al reo, sono state considerate in termini scarsamente problematici rispetto ad esigenze di limite e di contenimento, oggi come oggi si è invece venuti a "riscoprire" (ma forse sarebbe più veritiero dire "scoprire") tale esigenze di garanzia, soprattutto rispetto a quelle cause di giustificazione che si potrebbero definire positivistiche o pubblicistiche, ispirate cioè ad interessi collettivi e statali (es. adempimento del dovere, uso legittimo delle armi, attività dei servizi segreti) o che comunque sono riconducibili anche a una ratio di difesa sociale (come ad esempio la legittima difesa), le quali possono innescare un procedimento perverso volto a legittimare la forza contro i diritti fondamentali degli stessi cittadini». No es un caso, observa el autor (p. 606), que "le più grandi atrocità del secolo scorso [siano] state realizzate più con la giustificazione che mediante l'incriminazione”. Más en general, en el sentido de la necesidad de una renovada atención a la compatibilidad constitucional de las justificantes, aunque bajo el perfil de su influencia (en negativo) en el ámbito de la tutela penal asegurada a los derechos fundamentales, cfr. PALAZZO, Francesco, "Costituzione e scriminanti", Rivista italiana di diritto e procedura penale (2009), pp. 1033-1061, pp. 1033 y ss.

${ }^{84}$ Este nexo es, por otra parte, bien destacado ya por PULITANÒ, “Obblighi costituzionali”, cit. nota $\mathrm{n}^{\circ}$ 5, p. 514 ss., en relación al paradigma de las obligaciones constitucionales de tutela penal enucleadas por la Corte constitucional alemana. En el mismo sentido, pero con referencia específica también a la jurisprudencia del Tribunal de Estrasburgo, cfr. ROBBERS, Gerhard, "Strafpflichten aus der Verfassung", en: LÜDERSSEN, Klaus (Ed.), Aufgeklärte Kriminalpolitik oder Kampf gegen das Böse?, vol. I, Baden-Baden: Nomos, 1998, p. 150.
} 


\section{VIGANÒ, Francesco. "La arbitrariedad del no punir. Sobre las obligaciones de tutela penal de los derechos fundamentales".}

Un encuadramiento conceptual similar no constituye, ciertamente, una novedad en el panorama europeo, y aparece más bien recogido en sus rasgos esenciales del derecho constitucional alemán, al cual se le debe la categoría jurídica de la "obligación positiva", con la cual opera, también, el Tribunal europeo. Al lado de su contenido "clásico" (de carácter negativo) -comúnmente extraído de la expresión Abwehrrecht (que en su esencia es derecho "a no": a no ser privado de la libertad, a no ser torturado, a no ser encarcelado, etc., de parte del Estado, por medio de sus órganos)-, todo derecho fundamental tiene una dimensión deontológica ulterior, que el derecho constitucional alemán recoge con la expresión Schutzpflicht ("deber de tutela"): ${ }^{85}$ el reconocimiento de un derecho fundamental comporta, a cargo del Estado, también el deber de activarse para tutelar el disfrute del derecho contra agresiones ilícitas por parte de terceros, y correlativamente confiere al individuo una pretensión de que el Estado cumpla diligentemente tal deber. ${ }^{86}$

Según la doctrina constitucional alemana, tal "deber de tutela" de los derechos fundamentales -desarrollado por la Corte constitucional en aquel ordenamiento especialmente en relación al derecho a la vida y la salud ${ }^{87}$ - se declina, a nivel primario, en el deber de prohibir la comisión de hechos lesivos del derecho fundamental; y, en el nivel

${ }^{85}$ Cfr. por todos, a este respecto, MURSWIEK, Dietriech, "Art. 2", in Sachs-GGKommentar, IV ed., München: Beck, 2007, § 24 ss.

${ }^{86}$ Subraya perspicazmente ROBBERS, "Strafpflichten” cit. nota ${ }^{\circ}$ 84, p. 147 s. que la dimensión del derecho fundamental del Ahwehrrecht frente al Estado, usualmente individualizada por la doctrina constitucional (¡incluso en Italia!) como aquella históricamente más antigua, no era en realidad la única, y quizás ni siquiera la primera, a la cual pensaban las cartas de los derechos de finales del setecientos, expresión directa del pensamiento iluminista, al cual le importaba más bien afirmar la prioridad de los derechos fundamentales sobre el poder estatal. Por otra parte, la función primaria del poder estatal era la de ser instrumento para asegurar el goce de tales derechos de parte de los individuos, manteniendo las condiciones para su coexistencia pacífica. Incluso antes que en clave limitativa del poder soberano, los derechos fundamentales venían por lo tanto en consideración -en el pensamiento ilustrado- como razón y fundamento de tal poder, concebido en clave instrumental respecto a la tutela de los derechos, también y sobre todo en la relación entre privados. Observaciones en parte análogas son desarrolladas por PULITANÒ, “Obblighi costituzionali”, cit. nota $\mathrm{n}^{\circ} 5$, pp. 515 y ss., donde se subraya como los deberes positivos de tutela de los derechos fundamentales son conceptual e ideológicamente distintos a los deberes correspondientes a los, así llamados, derechos sociales (Leistungsansprüche, en la terminología usada por el constitucionalismo alemán), y atienden a un modelo de ordenamiento de marca francamente iluminista-liberal. "Disponer una tutela jurídica (¿penal?) [a los derechos fundamentales es] parte y presupuesto" - observa Pulitanò- "de cualquier ordenamiento estatal, que se ponga como marco y condición de la convivencia civil, superando la anarquía y la inseguridad del "estado de naturaleza"". La conformación de una tutela efectiva a tales derechos, prosigue el autor, "es, por ende, un problema que [...] toca las razones mismas de la relación autoridad-libertad: la legitimación de la autoridad estatal como instrumento de tutela, su dimensión como garantía liberal". En esta óptica, "incluso la teoría del Grundrechte adquiere una doble valor. El ordenamiento de la libertad, que caracteriza las constituciones democráticas, se pone como límite liberal infranqueable a la coacción estatal, como "derecho de defensa" de los individuos versus el Estado; al mismo tiempo, derechos y libertades fundamentales -en cuanto bienes jurídicos constitucionales- no pueden no ser punto de referencia privilegiado de una exigencia de defensa más radical, en todas las direcciones y con todos los medios de los cuales el estado democrático legítimamente dispone. Respeto y tutela de los derechos fundamentales para el legislador ordinario son, sin duda, una obligación. Una concepción unilateral de los Grundrechte como Ahwehrrechte, mera garantía de una esfera de inmunidad de la intervención estatal, aparece como insuficiente al interno de una perspectiva liberal, que trata de fundar y legitimar tareas e instrumentos de tutela estatal".

${ }^{87}$ Cfr. incluso MURSWIEK, “Art. 2”, cit. nota $n^{\circ} 85, \S 24$. 
secundario, en el deber de asegurar en el caso concreto la efectiva aplicación de tales normas por parte de los órganos estatales encargados. ${ }^{88}$

Deberes, por lo tanto, que vinculan a todos los poderes y órganos del Estado: del legislador al poder ejecutivo y a los jueces, cada uno en el ámbito de sus propias competencias.

Idéntica, decíamos, es la óptica en la cual se mueve la jurisprudencia de Estrasburgo, que como hemos visto ${ }^{89}$ reconoce desde hace tiempo -especialmente en materia de tutela del derecho a la vida - la obligación a cargo del Estado de predisponer en el caso concreto (y por lo tanto a nivel "secundario", según las mencionadas categorías constitucionales alemanas) adecuadas medidas de tutela de policía o judiciales de las personas reconociblemente enfrentadas a un peligro de lesiones de parte de terceros; deber que se combina al deber a cargo del legislador de tutelar en vía general y abstracta (y por lo mismo a nivel "primario") el derecho en cuestión, desarrollando un adecuado aparato normativo en grado de asegurarles una tutela efectiva.

El pasaje, sin embargo, desde la afirmación de la obligación de conformar la legislación en modo de garantizar la tutela efectiva del derecho (que, así formulada, se presenta como una mera obligación de resultado a cargo del Estado, que permanecería libre en la elección de los medios para conseguir su objetivo) a una obligación de tutelar el derecho en cuestión mediante el específico instrumento representado por el derecho penal, no es, sin embargo, banal. ${ }^{90}$ De hecho, el ius terrible es -entre los instrumentos de tutela de los derechos de los cuales el Estado dispone- aquel que al mismo tiempo es el más lesivo de otros derechos fundamentales, y de derechos fundamentales de la máxima relevancia: la libertad personal, el derecho a la vida privada y familiar y, en general, de la privacidad, el honor, la tranquilidad psíquica, el patrimonio, etc. Sobre estos derechos no sólo la sanción penal, sino ya las investigaciones y el proceso - con su conjunto de medidas cautelares y de instrumentos coercitivos- vienen fuertemente a incidir.

La decisión de utilizar el instrumento penal requiere, entonces, de una especial legitimación, que no puede basarse sólo en la consideración del rango (aunque fuese el más alto) del interés a tutelar, sino que debe pasar por un examen complejo que la ciencia penal contemporánea -al menos aquella parte de la ciencia penal influenciada por la doctrina alemana- sintetiza en la formula de la extrema (o última) ratio: la decisión de criminalización presupone no sólo que el interés a tutelar sea en abstracto tan relevante para ser considerado merecedor de tutela penal, reentrando entre las condiciones fundamentales de la ordenada convivencia civil, sino también que no existan alternativas menos lesivas de los derechos fundamentales idóneas para asegurar una tutela eficaz a los intereses en

\footnotetext{
${ }^{88}$ MURSWIEK, “Art. 2”, cit. nota ${ }^{\circ} 85, \S 27,33$.

${ }^{89}$ Cfr. supra, $\$ 3.1$.

90 Subraya justamente PULITANÒ, “Obblighi costituzionali”, cit. nota $\mathrm{n}^{\circ}$ 5, p. 519, la especifica problematicidad del recurso al instrumento de la coerción penal para satisfacer exigencias -en sí legitimas de tutela de los derechos fundamentales del individuo: "al afirmar obligaciones constitucionales de tutela penal, se afirma una conexión de principio entre deberes constitucionales de tutela, de por sí no problemáticos, y la obligación de adoptar soluciones penales. Al refutar tal asunto, se afirma la problematicidad de la coerción penal, vinculada a la naturaleza del instrumento y, por consiguiente, de los objetos de tutela".
} 
cuestión ("necesidad" de pena). Un examen que es fácilmente traducible -en categorías más familiares al lenguaje del derecho constitucional de cada ordenamiento contemporáneo, incluso aquellos de tradición anglosajona- en un juicio particularmente riguroso de proporcionalidad (en sentido amplio) entre el objetivo perseguido por el legislador y los medios adoptados; juicio que a su vez se decanta, al menos, en la verificación $a$ ) de la legitimidad del objetivo de tutela perseguido, $b$ ) de la idoneidad de la incriminación para conseguir tal objetivo de tutela, $c$ ) de la insustituibilidad de la incriminación con otros instrumentos de tutela menos lesivos e igualmente idóneos al objetivo de tutela, y finalmente $d$ ) de la proporcionalidad (en sentido estricto) entre el rango del interés tutelado y los derechos (fundamentales) lesionados precisamente por la intervención del derecho penal. ${ }^{91}$

Se trata, como es fácil de comprender, de valoraciones complejas, fundadas sobre datos fácticos de no inmediata identificación y fuertemente condicionados por los específicos contextos normativos, sociales y culturales, y que propiamente por esa razón se consideran comúnmente reservados, al menos en una primera instancia, al legislador democráticamente electo, por ser representativo de la entera sociedad unida por efecto del contrato social $^{92}$; mientras que las Cortes constitucionales o supremas se reservan, a lo más, un control ex post en clave limitativa de la decisión de criminalizaciones ya adoptada por los parlamentos, conforme a estándares muy respetuosos de la esfera de discrecionalidad del legislador.

No es casualidad que la crucial decisión de la Corte constitucional alemana de 1975 en relación a las obligaciones de tutela penal de la vida humana desde la concepción haya sido objeto, incluso en aquel ordenamiento, de ásperas críticas, ${ }^{93}$ en relación a su pretensión de imponer al legislador democráticamente electo una decisión positiva relativa a la efectiva criminalización del aborto, substrayéndole así la competencia a valorar discrecionalmente idoneidad, necesidad y proporción de la relativa criminalización respecto a la exigencia de tutela de un interés, cuyo estatus constitucional era además controvertido. Como han puesto de relieve los críticos de aquella histórica decisión, ${ }^{94}$ afirmar la existencia de un deber de tutela (Schutzpflicht) de la vida del feto, que se desprendería del art. 2 de la Constitución

91 Sobre este esquema, corriente incluso en la doctrina y la jurisprudencia constitucional alemana, cfr. PULITANÒ, "Giudizi di fatto nel controllo di costituzionalità di norme penali", Rivista italiana di diritto $e$ procedura penale (2008), pp. 1004-1037, p. 1027 (con ref. a la doctrina alemana). Para un reciente ejemplo relativo a la aplicación de este test cfr. BVerfG, sent. 26 febrero de 2008, 2 BvR 392/07, Rivista italiana di diritto e procedura penale (2009), pp. 2091 y ss., con un comentario de DODARO, Giandomenico, "La Corte costituzionale tedesca e l'incesto tra fratelli maggiorenni tra divieti culturali universali, incertezze della scienza e pretese dei diritti”.

${ }^{92}$ Lo recuerda, citando a Beccaria, PULITANÒ, “Obblighi costituzionali”, cit. nota n 5, p. 518 ss. El principio de legalidad (sub especie del reserva de ley) en materia penal expresaría más en particular, bajo el perfil de la repartición entre los poderes del Estado constitucional, una «afirmación de prevalencia, en la valoración de la necesidad de la coerción, del momento político-legislativo respecto a la misma predeterminación constitucional de valores y bienes tutelados».

${ }^{93}$ Cfr. la literatura citada en ROXIN, Strafrecht. Allgemeiner Teil, cit. nota ${ }^{\circ} 12$, p. 44.

${ }^{94}$ Así, uno de los más agudos críticos, entre los penalistas alemanes, de aquella sentencia (MÜLLER-DIETZ, Heinz, "Zur Problematik verfassungsrechtlicher Pönalisierungsgebote", en: Dreher-FS, Berlin: De Gruyter, 1977, p. 108). 
alemana, no significa necesariamente afirmar al mismo tiempo un deber de recurrir al derecho penal para asegurar su tutela, pues no es cierto que la criminalización sea la vía más eficaz para proteger la vida del concebido, respecto a otras formas pensables de intervención.

\subsection{Los argumentos utilizados por las Cortes: la efectividad de la tutela de los derechos y la capacidad disuasiva de la sanción penal}

Similares complejas valoraciones no se encuentran en las sucintas motivaciones de las sentencias de las dos Cortes internacionales a propósito de las obligaciones de tutela penal de los derechos fundamentales. ${ }^{95}$

Como ya se ha destacado, el punto de vista más frecuentemente evocado en estas sentencias -junto al genérico llamado a la efectividad de la tutela de los derechos- es aquel de la eficacia disuasiva de la sanción penal, que podría ser adecuadamente asegurada, en relación a las agresiones más graves, solamente con la amenaza de una pena. Este argumento es, por otra parte, simplemente enunciado, pero no analíticamente demostrado. Ninguna de las dos Cortes se ha detenido a aclarar por qué, por ejemplo, instrumentos alternativos y menos costosos en términos de derechos fundamentales -entre ellos, el recurso a sanciones administrativas o disciplinarias, o a la indemnización civil - deban ser a priori descartados como inidóneos para asegurar una efectiva disuasión respecto a potenciales autores, al punto que a los legisladores nacionales debería serle negada la posibilidad abstracta de una opción diversa que el recurso al derecho penal.

Por consiguiente, no es injustificada la duda que detrás de las afirmaciones de las dos Cortes se esconda en el fondo una apuesta sobre la función expresiva-simbólica del derecho penal, concebido como un instrumento de reconocimiento y de solemne proclamación de valores fundantes de una colectividad - de tal manera que la falta de tutela penal respecto de alguno de tales valores terminaría por indicar a la comunidad un déficit pernicioso de atención frente aquel valor, mientras su inserción en la tabla de valores diseñada en el código penal expresaría la voluntad del ordenamiento de "tomar en serio" la tutela de tales intereses. Una apuesta, por cierto, del todo disonante respecto a la prospectiva de un derecho penal de "ultima ratio" de la política social, que requiere siempre una legitimación ulterior respecto a la constatación del rango elevado del interés tutelado -en términos, como se ha recordado, de efectiva utilidad, no sustituibilidad y proporcionalidad (en sentido estricto) de la criminalización.

4.3. La búsqueda de las razones reales que inspiran la jurisprudencia: a) el nexo entre la tutela jurisdiccional efectiva de la víctima y la punibilidad de la conducta lesiva

Sin embargo, antes de cualificar esta jurisprudencia del Tribunal europeo y de la Corte interamericana como expresivas de meras razones simbólicas, creo que es importante

\footnotetext{
95 Destaca también esta laguna argumentativa en la jurisprudencia de la Corte NICOSIA, Convenzione
} europea, cit. nota $\mathrm{n}^{\circ} 46$, p. 259. 
VIGANÒ, Francesco. "La arbitrariedad del no punir. Sobre las obligaciones de tutela penal de los derechos fundamentales".

reflexionar un poco más sobre sus razones más profundas, más allá del tenor literal de las motivaciones de los fallos.

La hipótesis de trabajo que quisiera aquí presentar es que tales obligaciones están genéticamente conectadas a la lógica peculiar con la cual ambas Cortes se mueven, que es aquella de asegurar una tutela jurisdiccional efectiva a las víctimas de tales violaciones; tutela que las dos convenciones imponen que sea garantizada, primero que todo, de parte del ordenamiento interno (art. $13 \mathrm{CEDH}$ y art. $25 \mathrm{CADH}$ ), y que las Cortes aseguran sólo en clave subsidiaria, cuando los remedios internos se han revelados en el caso concreto ausentes o, en todo caso, inefectivos.

Consideremos la particular tipología de casos en los cuales las obligaciones en referencia vienen, en gran mayoría, afirmadas. Aunque la jurisprudencia de la Corte europea sobre obligaciones de tutela penal se haya inicialmente desarrollado en relación a casos de agresiones a derechos fundamentales ejecutadas por sujetos privados, a partir al menos de los últimos años de la década del noventa la afirmación de una obligación de tutela penal a cargo del Estado regularmente se encuentra en casos de ejecuciones arbitrarias, torturas y desapariciones forzadas ejecutadas por agentes estatales, los cuales cuentan con la complicidad, o al menos con la culpable inercia, de las más altas jerarquías civiles y militares; y es precisamente en relación a esta tipología de casos que ha madurado, desde el principio, la paralela jurisprudencia de la Corte interamericana.

Respecto a tales violaciones, la condición práctica esencial para que la víctima o sus familiares puedan recibir una tutela efectiva en el ordenamiento interno es que los hechos sean debidamente comprobados, y que sean individualizados los responsables de aquellas violaciones.

Tal tarea, todavía, no puede ser sensatamente realizada por la propia víctima, sino que únicamente por la autoridad pública y, más en concreto, por los órganos encargados del enforcement del derecho penal: policía, ministerios públicos y jueces, cada uno en el ámbito de sus respectivas competencias. Solamente estos órganos poseen, de hecho, los indispensables poderes coercitivos necesarios para romper el muro de silencio que, en general, acompaña la comisión de estas violaciones. Son ellos quienes poseen los necesarios recursos financieros necesarios para conducir investigaciones que son, en general, largas y complejas, justamente en razón de la falta sistemática de cooperación de parte de los órganos del poder policial. Son ellos, finalmente, quienes actúan - o deberían actuar, en todo Estado democrático- con un grado de independencia del poder ejecutivo suficiente para garantizar investigaciones efectivas y transparentes, en el ámbito de las cuales las víctimas tengan la posibilidad de hacer oír su propia voz.

En ausencia de investigaciones en sede penal, la tutela eventualmente ofrecida a la víctima en el plano del derecho civil se revelaría -empleando una expresión a menudo usada en la jurisprudencia del Tribunal europeo- simplemente ilusoria: ¿para qué serviría, de hecho, la abstracta titularidad de una acción resarcitoria, si el ordenamiento no le da a la víctima la posibilidad de conocer los hechos, y de individualizar a los autores de la violación sufrida? 
Polít. crim. Vol. 9, Nº 18 (Diciembre 2014), Art. 5, pp. 428-476.

[http://www.politicacriminal.cl/Vol_09/n_18/Vol9N18A5.pdf]

¿Contra quienes, y sobre la base de qué pruebas, podrían promover la acción civil los familiares de una persona desaparecida y, quizás, asesinada y torturada por algún escuadrón de la muerte? ¿Contra quienes - por mencionar un caso por fortuna menos dramático, pero más cercano a la experiencia italiana- habrían podido ejercitar una acción resarcitoria las víctimas de tortura en Génova, satisfaciendo en sede procesal las cargas probatorias que se le imponen a quien promueva en juicio en sede civil una acción de responsabilidad aquiliana, si la investigación llevada a cabo por la Fiscalía de Génova no hubiera puntualmente reconstruido los hechos e individualizado los autores materiales y morales de aquellos hechos?

Análogas interrogantes se podrían formular en todos aquellos casos, lamentablemente no infrecuentes incluso en mi país, de presos muertos en cárceles, cuando se sospeche que el deceso ha sido consecuencia de malos tratos sufridos de manos de los custodios.

Pero la indispensable condición para que las agencias de enforcement del derecho penal puedan desarrollar tales investigaciones es que la legislación vigente, de un lado, prevea tales hechos como delitos ( $¡ \mathrm{y}$ no en cambio como meros ilícitos civiles o disciplinarios!); y que, por otra parte, no prevea causas de justificaciones o causas de no punibilidad (incluso sobrevinientes, como la amnistía o el indulto), cuyos efectos puedan, en el caso concreto, paralizar las investigaciones, impidiendo así la efectiva comprobación de los hechos.

La obligación de tutela penal, en esta óptica, tiene su inmediata razón de ser no tanto en la perspectiva de la imposición de la pena contra quienes sean reconocidos responsables al término del proceso, sino que en la exigencia de consentir la realización de investigaciones penales, que a fin de cuentas constituyen el presupuesto esencial de cualquier tutela judicial efectiva para la víctima de la violación.

Las, así llamadas, obligaciones procesales impuestas al Estado, que la jurisprudencia de Estrasburgo deduce en particular de los arts. 2 y $3 \mathrm{CEDH}$, constituyen en esta perspectiva el prius de las obligaciones de criminalización: el Estado no puede, en el caso concreto, cumplir sus propias obligaciones de esclarecer lo acaecido, poniendo así a la víctima en condiciones de obtener tutela, si el hecho no tiene relevancia penal.

Idéntica es la perspectiva de la Corte interamericana, en cuya jurisprudencia se aprecia incluso mejor el acento sobre la obligación del Estado no sólo de proveer normativamente sanciones penales, sino sobre todo de activar la tutela penal a través de investigaciones de parte de los órganos competentes, con el objetivo de esclarecer los hechos constitutivos de las violaciones convencionales e individualizar a los responsables, lo que es una condición fáctica imprescindible para una tutela judicial efectiva para la víctimas de las violaciones.

Por otra parte, el nexo entre los deberes de incriminación de las conductas lesivas de derecho y el deber de activar investigaciones de parte de las instituciones competentes para aplicar el derecho penal se explica en función de garantía de la efectividad del derecho a la tutela jurisdiccional respecto a todas las víctimas que tienen condiciones económicas desventajosas, o que son más vulnerables -incluso cuando los autores de la violación no 
VIGANÒ, Francesco. "La arbitrariedad del no punir. Sobre las obligaciones de tutela penal de los derechos fundamentales".

sean agentes del Estado. Consideremos el mencionado caso Siliadin, en el cual el Tribunal europeo afirmó por primera vez una obligación de tutela penal del derecho a no ser sometido a esclavitud, servidumbre o trabajos forzados de parte de otros privados: ¿de cuál tutela jurisdiccional podría realísticamente valerse la víctima de una tal violación, si el Estado no se pone a su lado, a través de investigaciones penales iniciadas ex officio, y sin un costo económico a su cargo?

En esta óptica, las obligaciones de tutela penal no se muestran como el fruto de valoraciones improvisadas y aproximativas de merecimiento y necesidad de pena respecto a la exigencia de tutela preventiva del derecho fundamental (o del "bien jurídico" subyacente), según la cadencia típica del discurso penal; sino que derivan, en primer lugar, de la necesidad práctica de asegurar efectividad a la tutela jurisdiccional de los derechos fundamentales en los casos de agresiones ya acontecidas -al menos en relación, como se ha ampliamente subrayado, a los casos más graves, concernientes a los core rights convencionales.

\section{4. (Continuación) La función reparadora, en relación a la víctima, de la pena concretamente impuesta al autor}

Sin embargo, explicación que precede todavía no aclara porqué las dos Cortes insisten no sólo en la obligación a cargo del Estado de desarrollar investigaciones penales efectivas, idóneas para esclarecer los hechos e individualizar a los responsables, sino también en la obligación sucesiva de punir concretamente a los autores, imponiéndoles una pena proporcional a la gravedad del hecho.

Las dos Cortes parecieran, en efecto, asignar un significado autónomo a la imposición de la pena en relación a los responsables como medida reparatoria para las víctimas de las violaciones más graves, imprescindible incluso en los casos en los cuales se pueda, por otra vía, arribar al completo esclarecimiento de los hechos; tanto que, según la Corte interamericana, la concreta punición de los responsables, al menos de las violaciones más graves, no puede ser sustituida ni siquiera por las averiguaciones realizadas por comisiones de verdad y reconciliación en función de una pacificación colectiva. ${ }^{96}$

Significativa es, por otra parte, la insistencia del Tribunal europeo sobre la proporcionalidad de la pena respecto a la gravedad del hecho cometido, ${ }^{97}$ considerada expresión del principio no solamente de Überma $\beta$-, sino también de Untermaßverbot, ${ }^{98}$ o sea, en clave de medida mínima de la pena; con la consiguiente responsabilidad internacional del Estado cuando la pena en contra del autor de graves violaciones sea suspendida condicionalmente, o en todo caso resulte demasiado leve, en relación al hecho. Las motivaciones de las sentencias en las cuales estos principios vienen señalados -como

\footnotetext{
${ }^{96}$ Cfr. supra, $\S 2.2$. en correspondencia con la nota $\mathrm{n}^{\circ} 38$.

${ }^{97}$ Cfr. supra, $\$ 3.3$.

${ }^{98}$ Sobre esta dicotomía, con referencia específica a la relación entre la Constitución y los deberes de tutela de los bienes jurídicos, cfr. HASSEMER, "Strafrechtlicher Rechtsgüterschutz", cit. nota n 12, pp. 217 y ss.
} 


\section{Polít. crim. Vol. 9, № 18 (Diciembre 2014), Art. 5, pp. 428-476. [http://www.politicacriminal.cl/Vol_09/n_18/Vol9N18A5.pdf]}

en el reciente y emblemático caso Gäfgen c. Alemania, antes ya analizado ${ }^{99}$ - se apoyan, en efecto, en la ineficacia disuasiva de una pena demasiado baja respecto a futuros y potenciales autores de nuevas violaciones, especialmente si pertenecen a las estructuras de poder estatal, los cuales podrían así contar con su virtual impunidad. Pero no puede olvidarse que la lógica institucional de la intervención del Tribunal es, siempre, aquella de ofrecer tutela contra las violaciones en contra del recurrente individual, no de víctimas futuras o potenciales; y propiamente en esta lógica el Tribunal afirma, en esta misma sentencia, la insuficiencia de una tutela meramente resarcitoria, y la relacionada necesidad -en la lógica del derecho a un recurso efectivo de que trata el art. $13 \mathrm{CEDH}-$ de una tutela de naturaleza penal: consistente, en buena parte, ni más ni menos que en la condena de los autores de la violación a una pena en relación de justa proporción con la gravedad de la violación.

La atribución a la pena de una función así abiertamente reparatoria no está, evidentemente, exenta de problemas. La entera reflexión moderna sobre las funciones de la pena como alternativa a la pena privada (y, antes que eso, a la venganza) pareciera querer excluir de su horizonte a la víctima, cuya tutela debería ser asegurada por instrumentos distintos, in primis por la reparación del daño en sede civil; mientras la pena, y el derecho penal en su conjunto, debería en cambio hacerse cargo de la tutela de intereses colectivos, actuando en clave preventiva contra posibles futuras comisiones de nuevos hechos delictuales de parte de la generalidad de los individuos, como también de parte del propio condenado.

La jurisprudencia de las dos Cortes pretende, en cambio, restituir a la víctima un rol principal dentro del derecho y del proceso penal, concebidos ambos como instrumentos al servicio de sus derechos fundamentales. ${ }^{100}$

Esto se aplica, decíamos, ya en la etapa de las investigaciones y del proceso penal. La entera jurisprudencia europea sobre las obligaciones procesales surgida de los arts. 2 y 3 CEDH insiste sobre la necesaria participación de la víctima en las investigaciones; mientras la jurisprudencia interamericana, como se ha destacado previamente, incluso

\footnotetext{
${ }^{99}$ Cfr. supra, $\S 3.3$.

${ }^{100}$ Este punto de vista ha sido, en realidad, ampliamente discutido en los últimos años por la doctrina alemana en relación a un conocido caso que implicó a un profesor de literatura, Jan Philipp Reentsma, víctima de un secuestro, el cual escribió después un diario de sus treinta días de captura. En este diario, él formuló la tesis según la cual la imposición de la pena contra los autores tenía un preciso significado simbólico para la víctima, manifestando solemnemente que el Estado está de su parte. La tesis fue rápidamente identificada por destacados autores penalistas como una verdadera y propia teoría de la pena, de la cual no existen rasgos en los manuales de derecho penal y que es bien distinta a las tradicionales teorías retributivas, y que sin embargo corresponde a un dato socio sicológico real, que como tal no puede ser ignorado ni por el legislador ni por la jurisprudencia. La consideración del significado reparatorio de la pena para la víctima sería más bien funcional a la elaboración y a la superación del trauma sufrida por ella, del cual el Estado debería hacerse cargo (así, en particular, SCHRÖDER, Friedriech Christian, "Genugtuung für die Opfer, Reentsma und der Sinn der Strafe", in Frankfurter Allgemeine Zeitung del 19 marzo 1997, cit. en LÜDERSSEN, Klaus, "Opfer im Zwielicht”, in H.J.Hirsch-FS, Berlin: Walter De Gruyter, 1999, p. 886). Sobre la cuestión, y sobre el debate que se ha seguido en Alemania, véase en la literatura italiana la sintética recapitulación de TORDINI CAGLI, Silvia, Principio di autodeterminazione e consenso dell'avente diritto, Boloña: Bononia University Press, 2008, pp. 39 y ss.
} 
VIGANÒ, Francesco. "La arbitrariedad del no punir. Sobre las obligaciones de tutela penal de los derechos fundamentales".

desarrolla el derecho a ser oído por un juez - corolario del más amplio derecho al debido proceso- en relación a la posición de la víctima desde la etapa de investigación. El procedimiento penal en su globalidad, o sea, el proceso en sentido estricto, se convierte así en el lugar en el cual la víctima debe tener la posibilidad de hacer oír su propia voz, y en el cual el Estado, representado por el acusador público, se debe hacer cargo de su sufrimiento, poniéndose idealmente a su disposición en la búsqueda de la verdad y en la persecución de los responsables- especialmente cuando los responsables provengan del interior de los mismos aparatos estatales.

La concreta aplicación de la pena en contra del imputado declarado culpable al final del proceso devendrá, en este punto, una suerte de prueba de fuego de la seriedad de la decisión del Estado de ubicarse en el campo de la víctima, y no de sus torturadores.

Con esto las dos Cortes no entienden, naturalmente, fomentar brutales instintos de venganza, ni incentivar escenarios siniestros en los cuales a los familiares de las víctimas se les entregue la responsabilidad de decidir el tipo o la cantidad de pena, o incluso decidir la vida o la muerte del condenado: los dos convenios, y las dos paralelas jurisprudencias de este y el otro lado del Atlántico, no se limitan a tutelar con fuerza la posición del imputado durante el proceso -a menudo mucho más allá de los estándares asegurados en el ordenamiento italiano-, sino que también vigilan escrupulosamente que el tratamiento penitenciario del condenado no se traduzca nunca en un "tratamiento inhumano o degradante", condenando continuamente a los Estados por la violación de este esencial derecho en relación a la concretas condiciones de detención. ${ }^{101}$ Pero, según las dos Cortes, contra a quien se ha identificado como autor de graves violaciones de derechos humanos, una pena deberá ser concretamente impuesta, y una pena no sólo de fachada, para que sea expresada solemnemente la reprobación del ordenamiento por el hecho cometido.

Al esclarecimiento de la verdad deberá, en suma, seguir un juicio de reproche del hecho cometido, expresado por el ordenamiento mediante la aplicación de una pena no solamente simbólica (como sería una pena condonada o suspendida), sino que efectiva. Juicio de reproche que parece tanto más importante cuanto más el condenado sea parte, o haya sido parte, de los aparatos del Estado, con el objetivo de evidenciar públicamente la ruptura de la cadena de complicidad o de aquiescencia, que constituye el humus de esta clase de violaciones, en general fomentada con la seguridad de la futura impunidad.

De la función reparatoria de la pena podrá, en este punto, hablarse solamente en un sentido lato: esto es, en el sentido de restitución a la víctima -por medio del proceso y la condena de los responsables- de aquella dignidad de sujeto de derecho que los autores del crimen habían conculcado. La pena no elimina el delito, ni resarce a la víctima los daños sufridos para eso existen las reparaciones civiles-; pero es llamada, eso sí, a proclamar solemnemente (mucho más y mejor de cuanto no lo hace un resarcimiento pecuniario de parte del Estado) que la razón estaba de parte de la víctima, y el injusto de parte del condenado.

${ }^{101}$ Ejemplar resulta el caso Sulejmanovic c. Italia (ric. n. 22635/03), sent. 16 junio de 2009. 
Una reparación de carácter moral, que en todo caso las víctimas de los atentados más brutales a sus derechos fundamentales generalmente consideran muchísimo, y que constituye la razón de su activa participación incluso en los procesos en los cuales la perspectiva de obtener seriamente un resarcimiento de imputados insolventes es inexistente.

Del mismo modo, las víctimas valoran, especialmente, que la condena de los responsables suene como una advertencia a todos quienes en el futuro puedan ser tentados a cometer nuevamente similares violaciones. ${ }^{102}$ Una función como ésta es de evidente sentido general preventivo, y se combina con la lógica en sentido amplio reparatoria para la víctima, adoptada como hemos visto por las dos Cortes. "Para que todo esto no se repita nunca más" es, en efecto, el slogan en el cual muy a menudo se reconocen las víctimas de las agresiones más graves a derechos fundamentales, especialmente - una vez más- donde tales agresiones han estado perpetradas por los aparatos estatales. Un slogan detrás del cual se oculta la esperanza humana que el propio sacrificio no haya sido en vano, y que pueda servir al menos para reafirmar, en beneficio de otros, principios básicos de civilidad jurídica y de humanidad.

Esto también constituye una parte, y con entera propiedad, de la "justa satisfacción" que las víctimas pretenden, buscando el procesamiento y la condena de quienes han violado sus derechos fundamentales.

\subsection{Sobre la compatibilidad de las obligaciones de tutela penal de los derechos fundamentales con la reserva de ley prevista en el art. 25 inc. 2 de la Constitución italiana}

La tutela penal del derecho fundamental es condición práctica de la efectividad de la tutela jurisdiccional (supra, § 4.3), y la imposición al autor de la violación de una sanción adecuada al desvalor del hecho es una forma de necesaria reparación a la víctima (supra, § 4.4): así podríamos resumir el camino llevado a cabo hasta ahora, en la búsqueda de las razones profundas de las obligaciones de tutela penal establecidas por las dos Cortes en defensa de los core rights declarados en las respectivas Convenciones.

Se comparta o no este camino, queda aún por resolver, en este punto, el problema de la competencia de las dos Cortes internacionales para dictar obligaciones a los legisladores (y a las agencias de law enforcement) nacionales en el ámbito del derecho penal, especialmente donde -como en Italia- tales materias están, a nivel interno, cubiertas por la reserva de ley. Similares obligaciones excluyen, o al menos limitan fuertemente, la discrecionalidad del legislador nacional en la determinación acerca del sí y el quantum de la sanción penal, precluyéndole a priori de arribar a una valoración de no necesidad del instrumento penal en presencia de las más graves agresiones a aquellos core rights.

El argumento de la reserva de ley, a menudo invocado por la doctrina italiana contra las obligaciones supranacionales en materia penal, tiene en verdad dos aspectos, que no siempre vienen analíticamente identificados con la debida claridad. De un lado, (a) la

\footnotetext{
${ }^{102}$ Esta exigencia es, como se recordará, fuertemente enfatizada por la constante jurisprudencia del Tribunal europeo examinada supra, § 3.2 y 3.3 .
} 
reserva de ley tutela el principio de la división de poderes y, entonces, el principio democrático que le encomienda al órgano directamente representativo -y a su mayoría- el monopolio de las decisiones de criminalizar, que fuertemente inciden sobre los derechos fundamentales de los ciudadanos (reserva de ley parlamentaria). ${ }^{103}$ Por otro lado, $(b)$ la reserva de ley establecida por el art. 25 inc. 2 de la Const. italiana es -al menos implícitamente- entendida como reserva de ley nacional, y entonces como prerrogativa de la soberanía estatal en materia penal, que sería como tal refractaria a los condicionamientos de la comunidad internacional (reserva de ley estatal). ${ }^{104}$

4.5.1. En relación al primer aspecto, podría de hecho argumentarse que jueces carentes de toda representatividad democrática, y designados por los gobiernos de los Estados partes, no tienen ninguna legitimación para dictar reglas vinculantes en materia penal, que están constitucionalmente -al menos en Italia- reservadas al legislador elegido por el pueblo. Ergo, el legislador debería siempre considerarse libre de no aceptar las indicaciones de aquellos jueces.

Una visión así, sin embargo, no le haría justicia a la realidad del sistema de las fuentes, incluso en materia penal.

Para comenzar: en todo ordenamiento constitucional, es pacífico que el parlamento rectius, la mayoría parlamentaria- no es el único árbitro de las elecciones punitivas. El nullum crimen sine lege expresa una reserva a favor del parlamento en contraposición al ejecutivo y judicial; pero no excluye, obviamente, un control de la compatibilidad de las decisiones del parlamento con la Constitución y, en general, con los vínculos supra legislativos.

Tal control es necesariamente confiado a organismos diversos $e$ independientes del parlamento, y de la mayoría que representa, aunque sólo sea por la evidente razón que el controlador no puede coincidir con el controlado; y es en efecto confiado, en todos los ordenamiento contemporáneos, a órganos jurisdiccionales (ordinarios o, como en el caso del ordenamiento italiano, a una Corte constitucional) desprovistos de legitimación democrática, precisamente porque su tarea es aquella de ponderar la compatibilidad de las decisiones del pueblo (y de sus directos representantes) con los vínculos a los cuales el mismo pueblo se ha sometido mediante el pacto constitucional, o bien mediante la adhesión, deliberada por sus propios representantes, a convenciones internacionales que fijan límites a su discrecionalidad en esta o aquella esfera. Y esto vale, naturalmente, incluso en las materias cubiertas por la reserva de ley, como el derecho penal.

\footnotetext{
${ }^{103}$ Se trata de la ratio asignada corrientemente al principio por la manualistica: cfr. por todos, MARINUCCI, Giorgio; DOLCINI, Emilio, Manuale di diritto penale, III ed., Milano: Giuffrè, 2009, p. 33.

${ }^{104}$ En este sentido puede ser leída, por ejemplo, la tesis de INSOLERA, Gaetano, Democrazia, ragione, prevaricazione, Milano: Giuffrè, 2003, p. 62, según el cual la reserva de ley de que trata el art. 25 inc. 2 de la Const. italiana constituiría un contra límite (según el contenido de la sent. 170/1984) respecto a las limitaciones a la soberanía derivadas de los arts. 11 y 117 inc. 1 de la Const. italiana, cuanto menos hasta que las instituciones supranacionales de las cuales provengan obligaciones de criminalización no logren llenar el déficit de representatividad democrática que todavía las caracteriza.
} 


\section{Polít. crim. Vol. 9, № 18 (Diciembre 2014), Art. 5, pp. 428-476. \\ [http://www.politicacriminal.cl/Vol_09/n_18/Vol9N18A5.pdf]}

Como se ha evidenciado desde el inicio de esta contribución, sin embargo, el problema es que el control de las cortes constitucionales sobre las elecciones legislativas concernientes a la materia penal ha sido tradicionalmente pensado en clave negativa: a la ley le estaría prohibido prever la sanción penal en relación a ciertas conductas (v. gr. al estar cubiertas por libertades constitucionales, o porque su punición aparecería contraria al principio de igualdad, etc.), pero no le se podría imponer de prever esta sanción para la tutela de bienes jurídicos. Aquí la discrecionalidad del legislador pareciera ser absoluta.

A primera vista, la distinción parece plausible: es solo la elección de punir, se podría observar, que compromete los derechos fundamentales del destinatario del precepto y, por lo mismo, de la sanción penal. Pero el argumento no considera que incluso la elección de no punir tiene una inmediata incidencia sobre los derechos fundamentales de la víctima, dejándola sin tutela -lo que se verifica, en particular, en los casos en los cuales los instrumentos de tutela extrapenal en teoría disponibles se revelan en la práctica inefectivos. No sancionar a los autores de tortura significa, ni más ni menos, dejar sin protección los derechos fundamentales de las víctimas de aquellas torturas.

De hecho, el legislador puede actuar arbitrariamente tanto en la elección de punir, como en aquella de no punir; ${ }^{105}$ y el deber de tutela de los derechos fundamentales, que recae sobre el legislador por efecto tanto de la Constitución como de los instrumentos internacionales, puede legítimamente interpretarse tanto en el sentido de prohibir el recurso a la pena, así como de imponerlo, cada vez que la previsión de sanciones penales resulte evidentemente necesaria para ese objetivo.

El nudo problemático en este punto no es tanto, a mi juicio, aquel de la legitimación de este desarrollo por vía hermenéutica de parte de las Cortes (constitucionales o internacionales) de verdaderas obligaciones de tutela penal de los derechos fundamentales, sino más bien de poner límites estrictos al control de las decisiones del legislador por parte de las Cortes, para evitar que este control se sobreponga a la valoración, normalmente reservada al legislador democráticamente elegido, sobre la necesidad de recurrir al instrumento penal y, más en general, sobre su proporcionalidad, ya que tales valoraciones presuponen delicadas ponderaciones sobre los pro y los contras del uso de la coerción penal, a las cuales siempre están asociados efectos lesivos de los derechos fundamentales de los individuos. Pero cuanto menos el límite de la manifiesta irracionalidad de la elección legislativa, que marca el punto en el cual la discrecionalidad reservada al poder legislativo raya en la arbitrariedad, bien podrá ser hecho valer por las mismas Cortes: tanto respecto a la elección de punir, ${ }^{106}$ como a aquella de renunciar a la pena. ${ }^{107}$

\footnotetext{
${ }^{105}$ Lo que, por lo demás, ha sido reconocido por la misma Corte constitucional italiana, que justamente sobre tal decisivo argumento centra su jurisprudencia que admite un control de constitucionalidad sobre las, así llamadas, normas penales favorables: cfr. por todos, el denso análisis de MARINUCCI, "Il controllo di legittimità costituzionale", cit. nota $\mathrm{n}^{\circ} 8, \mathrm{pp} .4160$ y ss.

${ }^{106}$ Lo que es pacífico en la jurisprudencia constitucional italiana, que precisamente utiliza de modo general el límite de la manifiesta irracionalidad para controlar la decisión de incriminación realizada por el legislador: cfr. la última, C. const., sent. 250/2010, y sus precedentes ahí citados.

${ }^{107}$ Instructivo, a este propósito, el denso (aunque no reciente) libro di MARXEN, Rechtliche Grenzen, cit. nota $\mathrm{n}^{\circ} 29$. Recuerda antes que todo el autor (p. 5) que, durante la época nacionalsocialista, las amnistías eran
} 
La tutela (y la tutela efectiva) de los derechos fundamentales, después de todo, no puede depender de las contingentes decisiones de los detentadores del poder, aún cuando estos últimos hayan sido elegidos democráticamente. El principio democrático encuentra aquí un límite preciso, connatural al marco constitucional en el cual se ejercita la misma soberanía popular. La tutela de los derechos de las minorías y de los más débiles es una de las tareas fundamentales de todo ordenamiento jurídico, y ciertamente de los ordenamientos jurídicos fundados sobre la base del respeto de tales derechos (rectius, sobre el "reconocimiento" de aquellos derechos, entendidos como preexistentes sobre el plano axiológico respecto a los mismos ordenamientos, que nacen propiamente en función de su protección); y tal tutela con todos los medios necesarios para el objetivo, incluyendo los instrumentos penales, cuando aparezca claramente que no pueden ser sustituidos por instrumentos alternativospodrá y deberá hacerse valer, si es el caso, aunque contra la voluntad de la mayoría. ${ }^{108}$

4.5.2. Si bien no pareciera posible a priori negarle a órganos diversos del poder legislativo, y en particular a las jurisdicciones constitucionales nacionales, un control sobre la legitimidad de la decisión de punir y de no punir efectuada por la mayoría a través de sus representantes elegidos en el parlamento, el problema que nos queda es establecer si tal poder puede ser reconocido también a jurisdicciones supranacionales, como son el Tribunal Europeo y la Corte interamericana.

la otra cara de la brutalidad del poder, sustrayendo sistemáticamente a las investigaciones por parte de la policía y del ministerio público a los autores de hechos gravísimos, coludidos con, o instigados por, los aparatos del gobierno. La impunidad garantizada de esa manera a los autores era una expresión de abuso de poder, así como lo era el empleo del derecho penal como medio de neutralización de la disidencia política (p. 6), ambos instrumentos abriendo la puerta a un tratamiento (¡macroscópicamente!) diferenciado para "amigos" y "enemigos" políticos. "Un Estado que pretenda el monopolio del uso de la fuerza" -destaca el autor (p. 7)- "puede violar en dos modos el deber de asegurar la garantía en el disfrute de los derechos: excediéndose en el uso de la coerción, pero también usando de manera insuficiente la coerción. En ambos casos los ciudadanos devienen objeto de un abuso del poder, por ser injustamente perseguidos penalmente, o por permanecer víctimas de la opresión ajena". Del todo consecuentemente, la obra concluye afirmando la ilegitimidad constitucional de la amnistía respecto a hechos lesivos de bienes jurídicos por los cuales subsista una obligación constitucional de tutela penal (p. 57).

${ }^{108}$ Así, incisivamente, ROBBERS, Strafpflichten, cit. nota n 84, p. 155. El mismo Pulitanò, que por supuesto no reconoce la existencia de verdaderas obligaciones de tutela penal, de acuerdo al principio de que la decisión de accionar el derecho penal debería quedar reservada al legislador democráticamente electo, reconoce que "el reenvío a la soberanía/responsabilidad del legislador garantiza la apertura del sistema constitucional y penal-, pero no la calidad de las soluciones", agregando que "la búsqueda de garantías más vinculantes es, por lo tanto, comprensible ahí donde se trate de cuestiones fundamentales de tutela", sin excluir en absoluto que pueda existir "una área de eventuales, excepcionales obligaciones de penalización como instrumento necesario para la tutela de los derechos fundamentales" (PULITANÒ, "Obblighi costituzionali", cit. nota $\mathrm{n}^{\circ} 5$, pp. 522 y ss.). Lo que es exactamente lo que han sostenido las cortes internacionales, que circunscriben -como se ha visto ampliamente en las páginas precedentes- la extensión de las obligaciones de tutela penal propiamente a un contenido mínimo de agresiones voluntarias a los derechos más fundamentales del individuo (y en particular a la vida $\mathrm{y}$ al derecho a no ser sometido a torturas o desapariciones forzadas). La impresión es, entonces, que la discusión italiana sobre las obligaciones constitucionales de tutela penal ha estado prematuramente archivada, por efecto de lo extremamente controvertido de las tipologías de hipótesis en las cuales tales obligaciones han sido proyectadas en la experiencia judicial italiana y alemana de los años setenta (aborto y tutela penal del medio ambiente); y que tales discusiones, por tanto, perfectamente pueden retomarse hoy a la luz de otras tipologías de situaciones. 
Polít. crim. Vol. 9, Nº 18 (Diciembre 2014), Art. 5, pp. 428-476.

[http://www.politicacriminal.cl/Vol_09/n_18/Vol9N18A5.pdf]

Al referirse a las obligaciones de tutela penal derivadas del deber de tutela de los derechos humanos, no se puede omitir un dato crucial: con el despertar del mundo después de la pesadilla de la Segunda Guerra Mundial, la comunidad internacional ha asumido inmediatamente como propia la tarea de la protección de los derechos fundamentales -a nivel mundial, con la Declaración de las Naciones Unidas de 1948 (y la paralela Convención de Ginebra de 1949, con el objetivo de la tutela de los derechos humanos en tiempo de guerra); y a nivel regional, en particular, mediante la Convención europea de 1950 y más tarde mediante la Convención americana-, imponiendo así vínculos a los Estados sobre un plano diverso y ulterior respecto a cuanto estaba ya asegurado a nivel interno desde las respectivas constituciones. La experiencia trágica de los años precedentes había, de hecho, mostrado la insuficiencia de la protección de los derechos esenciales, como el derecho a la vida, a no ser sometido a tortura, a la libertad personal, etc., otorgada por constituciones suspendidas sin mayores problemas frente a presuntos estados de emergencia o necesidades nacionales; y había así indicado la necesidad de una tutela de esos mismos derechos de parte del derecho internacional, de modo que los Estados (y sus órganos en cuanto personas físicas) pudiesen ser llamados a responder ante la comunidad internacional, en caso de violaciones de esos derechos.

Los Estados que dieron vida al Convenio europeo quisieron dar un paso más en esta dirección, llegando a instituir un órgano jurisdiccional, confiándole la doble función $a$ ) de interpretar de manera auténtica el Convenio, y $b$ ) de decretar las violaciones de parte de los Estados miembros, en el marco de un procedimiento absolutamente inédito -desde el punto de vista del derecho internacional- iniciado por un particular que alega ser víctima de una violación.

Ahora bien, las dos Cortes ciertamente se han tomado en serio esta doble función: decretando una avalancha de violaciones de parte de los Estados miembros, en un número siempre creciente en el curso de los últimos años, pero también interpretando de un modo muy libre, y en cierto sentido creativo, las respectivas convenciones, apreciándolas como living instruments y leyéndolas no según el criterio restrictivo de la reconstrucción de la voluntad histórica de sus redactores, sino que según las exigencias de una sociedad en continua evolución, a la cual aquellos instrumentos deben ser continuamente ajustados mediante la interpretación. Eso ha implicado un constante enriquecimiento, en vía jurisprudencial, de los contenidos deontológicos expresados en los datos textuales, a menudo muy lacónicos, de las normas convencionales, según un modus operandi común por lo demás- a aquel utilizado por todas las jurisdicciones constitucionales nacionales, también confrontadas con textos que datan de décadas, o incluso siglos (como en el caso emblemático de la Corte Suprema estadounidense, cuya jurisprudencia le confiere una forma siempre nueva a un Bill of Rights que, en su núcleo central, fue escrito a finales del setecientos por redactores que, no conociendo ni siquiera la ferrovía, ciertamente no podían prever que la Corte que estaban creando debería ocuparse de interceptaciones telefónicas, de internet o de fecundaciones asistidas).

El rol de interpretes calificados, y de hecho de últimos interpretes, de las respectivas convenciones no es, por otra parte, una invención de las dos cortes, sino que ha sido 
VIGANÒ, Francesco. "La arbitrariedad del no punir. Sobre las obligaciones de tutela penal de los derechos fundamentales".

expresamente a ellas conferido por la voluntad soberana de los Estados, manifestada en el acto de la ratificación de la convenciones y mantenida. El art. $32 \mathrm{CEDH}$, por ejemplo, textualmente indica: "la competencia del Tribunal se extiende a todos los asuntos relativos a la interpretación y la aplicación del Convenio y sus protocolos" a ella ritualmente sometidos. Los Estados se han obligado entonces en el plano internacional a someterse a la interpretación que el Tribunal realizaría del Convenio.

Desde que el Estado es, en el sistema convencional, el primer garante de los derechos fundamentales reconocidos en el Convenio, debiendo "asegurar" a nivel interno su respeto (art.1 de ambas convenciones) y su tutela jurisdiccional efectiva (art. 13 CEDH, art. 25 $\mathrm{CADH}$ ), entonces el Estado deberá - para no incurrir en una responsabilidad internacionalasegurar en el propio ordenamiento la tutela a tales derechos conformemente a las interpretaciones de las cortes, que son sus garantes e intérpretes finales.

Esto no puede no valer incluso en materias que, como el derecho penal, están cubiertas a nivel interno por una reserva de ley fundada en la Constitución. Mediante la adhesión a un tratado internacional del cual descienden obligaciones de tutela penal de los derechos fundamentales en el ordenamiento interno, el Estado italiano ha, en particular, aceptado una verdadera limitación de la propia soberanía, que además es constitucionalmente legítima en cuanto resulta- en el sentido del art. 11 Const.- funcional a la realización de un ordenamiento (supranacional) que asegure la paz y la justicia entre las naciones; y ha aceptado una correlativa limitación de la propia potestad legislativa, vinculándose a ejercerla entre los límites fijados por aquellas obligaciones internacionales, así como precisados y definidos por la jurisprudencia del Tribunal (art. 117 inc. 1 Const).

Por lo que concierne entonces al ordenamiento italiano, la reserva de ley en materia penal establecida por el art. 25 inc. 2 de la Const. supone ciertamente una barrera a fuentes subordinadas respecto a la ley estatal en materia penal; pero no podrá, en cuanto, tal ser invocada como contra-límite respecto a las limitaciones de soberanía necesariamente descendientes de la adhesión de Italia al CEDH. Estas limitaciones de soberanía naturalmente interfieren con la materia penal: poniendo límites, como se ha visto, sea al poder de punir, sea aquel de no punir de parte del legislador interno, en la óptica de asegurar una dimensión efectiva -y no meramente de papel o declaratoria- a aquellos mismos derechos.

\section{Conclusiones}

Mientras en Roma se sigue discutiendo, la ciudad fortificada de la reserva de ley (parlamentaria y nacional) está por capitular, o ya ha capitulado, de frente al asalto de fuerzas centrípetas que intentan expropiar al legislador italiano de la propia discrecionalidad en materia penal; poniéndole límites no sólo al poder de incriminar conductas y de punir a sus autores, sino también a su prerrogativa de no ejercer el poder punitivo, mediante la imposición de obligaciones de criminalización (en abstracto) y de efectiva punición (en el caso concreto). Y todo esto en una lógica de tutela de los derechos fundamentales del individuo: tradicionalmente pensados en clave de protección contra los 
Polít. crim. Vol. 9, № 18 (Diciembre 2014), Art. 5, pp. 428-476.

[http://www.politicacriminal.cl/Vol_09/n_18/Vol9N18A5.pdf]

abusos del poder punitivo estatal, pero considerados ahora, por las dos cortes internacionales, también como razones que reclaman su intervención.

Es comprensible, entonces, el desconcierto de muchos penalistas, italianos y extranjeros, en relación a similar desarrollo.

Las reflexiones que preceden deberían, sin embargo, haber mostrado que los agresores de esa ciudadela fortificada no son, como quizás no lo eran ni siquiera los Cartagineses de Aníbal, hordas de bárbaros brutos e incultos. Por el contrario: solidas razones, si se observa bien, militan de su parte; y estas revolucionarias tesis no están privadas de legitimación, desde el punto de vista del derecho internacional, así como desde el punto de vista del contexto constitucional interno.

El poder punitivo estatal puede ser usado en modo arbitrario no sólo cuando se le ejerce, sino también cuando se omite ejercerlo, dejando así sin tutela a víctimas débiles. El deber a cargo del Estado de tutelar los derechos más fundamentales de los individuos (a no ser secuestrados y después ejecutados por algún escuadrón de la muerte constituido en el seno de las fuerzas armadas, pero también a no ser privados de libertad por la detención de un paquete de cocaína para luego ser objeto de brutales golpizas de parte de la policía, como ocurre, lamentablemente, incluso en Italia) comporta el deber no sólo de proveer sanciones penales dotadas de un efectivo potencial disuasivo, sino incluso - una vez ocurrida la violación- de activar ex officio investigaciones independientes, idóneas para permitir en el caso concreto la individualización de los responsables y su efectiva punición, como resultado de un proceso en el cual el Estado se hace cargo del sufrimiento de la víctima y de sus familiares, ayudándoles a superar el trauma sufrido, a través de la solemne estigmatización de la conducta de los culpables. Todo esto, naturalmente, con el pleno respeto de los derechos de los imputados a un proceso justo e imparcial, y con completo reconocimiento - a su turno- de su dignidad de personas y de sus derechos fundamentales, incluso una vez que han sido declarados culpables de los delitos más atroces.

No se trata, creemos, de afirmaciones extravagantes, ni siquiera para la doctrina italiana. En ese sentido observa perspicazmente Pulitanò, a propósito del mismo principio de legalidad de que trata el art. 25 inc. 2 Const., que usualmente sólo se entiende como garantía del particular contra el jus puniendi:

"el principio de legalidad, que exige una aplicación de la ley igual para todos, y el principio de obligatoriedad de la acción penal, que es su cara procesal, orientan (también) hacia el finalismo represivo la máquina judicial globalmente considerada. El problema factual de la productividad del sistema de justicia, en términos de correcto y eficaz esclarecimiento del hecho y determinación de la responsabilidad de los autores de los delitos (en suma: de 'aplicación de la ley punitiva'), no puede ser excluido de las finalidades del sistema, sino que concurre a definir, junto a la calidad de las garantías 'liberales', la contribución de la jurisdicción penal a la tutela de los intereses que se quieren legalmente proteger." 109

${ }^{109}$ PULITANÒ, Diritto penale, cit. nota n ${ }^{\circ} 8$, p. 48. 
VIGANÒ, Francesco. "La arbitrariedad del no punir. Sobre las obligaciones de tutela penal de los derechos fundamentales".

El deber de perseguir y de punir los delitos, en el respeto de criterios de igualdad es, si se mira bien, la otra cara del principio de legalidad. Sobre todo, agregamos, cuando los intereses tutelados por la norma penal son representados por derechos fundamentales de los individuos, especialmente de los más débiles frente a la prevaricación de los más fuertes; derechos que el Estado democrático, le guste o no, tiene el preciso deber-asumido frente a la entera comunidad internacional- de no dejar sin aquella tutela efectiva, que solamente puede ser asegurada por el ejercicio de la jurisdicción penal. 
Polít. crim. Vol. 9, № 18 (Diciembre 2014), Art. 5, pp. 428-476.

[http://www.politicacriminal.cl/Vol_09/n_18/Vol9N18A5.pdf]

\section{BIBLIOGRAFÍA}

BARTOLI, Roberto, "Incriminazione e giustificazione: una diversa legalità?", Rivista italiana di diritto e procedura penale (2010), pp. 597-632.

BESTAGNO, Francesco, Diritti umani e impunità. Obblighi positivi degli Stati in materia penale, Milano: Vita e Pensiero, 2003.

BONOMI, Andrea, Il "limite" degli obblighi internazionali nel sistema delle fonti, Torino: Giappichelli, 2008.

COLELLA, Angela, "C'è un giudice a Strasburgo. In margine alle sentenze sui fatti della Diaz e di Bolzaneto: l'inadeguatezza del quadro normativo attuale in tema di repressione penale della tortura", Rivista italiana di diritto e procedura penale (2009), pp. 1801-1843.

CHENAL, Roberto, "Obblighi di criminalizzazione tra sistema penale italiano e Corte europea dei diritti dell'uomo", La legislazione penale, vol. no 26 (2006), pp. 171-190.

DELMAS-MARTY, Mireille, Dal codice penale ai diritti dell'uomo, Milano: Giuffrè, 1992.

, "Politica criminale e diritti dell'uomo in Europa", Indice penale, año XXII, n 2 (1988), pp. 205-216.

DONINI, Massimo, Il volto attuale dell'illecito penale, Milano: Giuffrè, 2004.

DODARO, Giandomenico, "La Corte costituzionale tedesca e l'incesto tra fratelli maggiorenni tra divieti culturali universali, incertezze della scienza e pretese dei diritti”, Rivista italiana di diritto e procedura penale, (2009), pp. 2091 y ss.

ESPOSITO, Andreana, Il diritto penale flessible: quando $i$ diritti umani incontrano $i$ sistemi penali, Torino: Giappichelli, 2008.

FIANDACA, Giovanni, "Legalità penale e democrazia", en: Quaderni fiorentini per la storia del pensiero giuridico moderno, 2007.

FRONZA, Emanuela, Il principio di complementarità, esercizio delle giurisdizione e adeguamento a livello interno, en: AMATI, Enrico et. al. (Eds.), Introduzione al diritto penale internazionale, Milano: Giuffrè, 2006.

INSOLERA, Gaetano, Democrazia, ragione, prevaricazione, Milano: Giuffrè, 2003.

MAIELLO, Vincenzo, Clemenza e sistema penale, Napoli: ESI, 2007.

MALARINO, Ezequiel, "Il volto repressivo della recente giurisprudenza argentina sulle gravi violazioni dei diritti umani", en: FRONZA, Emanuela; FORNASARI, Gabriele (Eds.), Il superamento del passato e il superamento del presente, Trento: Università di Trento Ed., 2009.

MARINUCCI, Giorgio, "Il controllo di legittimità costituzionale delle norme penali: diminuiscono (ma non abbastanza) le «zone franche»", Giurisprudenza costituzionale (2006), pp. 4160-4170.

MARINUCCI, Giorgio; DOLCINI, Emilio, Corso di diritto penale, III ed., Milano: Giuffrè, 2001.

Manuale di diritto penale, III ed., Milano: Giuffrè, 2009.

MARXEN, Klaus, Rechtliche Grenzen der Amnestie, Heidelberg: Müller Verl., 1984.

MOWBRAY, Alastair, The Development of Positive Obligations under the European Convention on Human Rights by the European Court of Human Rights, Portland: Hart, 2004. 
VIGANÒ, Francesco. "La arbitrariedad del no punir. Sobre las obligaciones de tutela penal de los derechos fundamentales".

MÜLLER-DIETZ, Heinz, “Zur Problematik verfassungsrechtlicher Pönalisierungsgebote”, en: Dreher-FS, Berlin: De Gruyter, 1977.

MURSWIEK, Dietriech, “Art. 2", in Sachs-GGKommentar, IV ed., München: Beck, 2007.

NICOSIA, Emanuele, Convenzione europea dei diritti dell'uomo e ordinamiento penale, Torino: Giappichelli, 2006.

PALAZZO, Francesco, "Costituzione e scriminanti”, Rivista italiana di diritto e procedura penale (2009), pp. 1033-1061.

PAONESSA, Caterina, Gli obblighi di tutela penale. La discrezionalità legislativa nella cornice dei vincoli costituzionali e comunitari, Pisa: ETS, 2009.

PARENTI, Pablo, "La persecuzione penale di gravi violazioni dei diritti umani in Argentina", en: FRONZA, Emanuela; FORNASARI, Gabriele (Eds.), Il superamento del passato e il superamento del presente, Trento: Università di Trento Ed., 2009.

PASTOR, Daniel, "Processi penali solo per conoscere la verità? L'esperienza argentina", en: FRONZA, Emanuela; FORNASARI, Gabriele (Eds.), Il superamento del passato e il superamento del presente, Trento: Università di Trento Ed., 2009.

PULITANOे, Domenico, "Obblighi costituzionali di tutela penale", Rivista italiana di diritto e procedura penale (1983), pp. 484-528.

, "Giudizi di fatto nel controllo di costituzionalità di norme penali", Rivista italiana di diritto e procedura penale (2008), pp. 1004-1037.

, Diritto penale, III ed., Torino: Giappichelli, 2009.

ROBBERS, Gerhard, "Strafpflichten aus der Verfassung”, en: LÜDERSSEN, Klaus (Ed.), Aufgeklärte Kriminalpolitik oder Kampf gegen das Böse?, vol. I, Baden-Baden: Nomos, 1998.

ROMANO, Mario, Repressione della condotta antisindacale. Profili penali, Milano: Giuffrè, 1974.

, Commentario sistematico del codice penale, vol. I, III ed., Milano: Giuffrè, 2004.

, "Corte costituzionale e riserva di legge", en: VASSALLI, Giuliano (Ed.), Diritto penale e giurisprudenza costituzionale, Napoli: ESI, 2006.

"Complessità delle fonti e sistema penale. Leggi regionali, ordinamento comunitario, Corte costituzionale", Rivista italiana di diritto e procedura penale (2008), pp. 538-558.

ROMANO, Mario; STELLA, Federico, Aborto e legge penale, Riflessioni e proposte, Milano: Giuffrè, 1975.

ROXIN, Claus, Strafrecht. Allgemeiner Teil, vol. I, IV ed., München: Beck, 2006.

SANTANA VEGA, Dulce Maria, "Diritto penale minimo e obblighi costituzionali taciti di tutela penale", Dei delitti e delle pene (2000), pp. 47-67.

SCHRÖDER, Friedriech Christian, "Genugtuung für die Opfer, Reentsma und der Sinn der Strafe", in Frankfurter Allgemeine Zeitung del 19 marzo 1997,

TORDINI CAGLI, Silvia, Principio di autodeterminazione e consenso dell'avente diritto, Boloña: Bononia University Press, 2008.

VIGANO, Francesco, "Diritto penale sostanziale e Convenzione europea dei diritti dell'uomo", Rivista italiana di diritto e procedura penale, (2007), pp. 42-99.

, "Il diritto penale sostanziale davanti ai giudici della CEDU", Giurisprudenza di merito, suppl. al vol. XL (2008), pp. 81-112. 
Polít. crim. Vol. 9, № 18 (Diciembre 2014), Art. 5, pp. 428-476.

[http://www.politicacriminal.cl/Vol_09/n_18/Vol9N18A5.pdf]

"Droits de 1'homme et droit pénal: Un hommage à Sergio García Ramírez", Cahiers de défense sociale (2009-2010), pp. 83-93.

, "Il giudice penale e l'interpretazione conforme alle norme sopranazionali", en: CORSO, Piermaria; ZANETTI, Elena, Studi in onore di Mario Pisani, vol. II, Piacenza: La Tribuna, 2010. 